\title{
Imaging Spectrometry of Inland and Coastal Waters: State of the Art, Achievements and Perspectives
}

\author{
C. Giardino ${ }^{1}$ (D) - V. E. Brando ${ }^{2} \cdot$ P. Gege ${ }^{3}$ N. Pinnel ${ }^{4} \cdot$ E. Hochberg 5 •

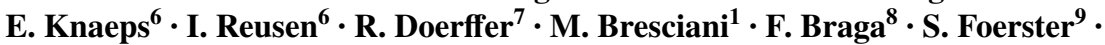 \\ N. Champollion ${ }^{10,11} \cdot$ A. Dekker ${ }^{12}$
}

Received: 6 October 2017 / Accepted: 8 May 2018 / Published online: 5 June 2018

(C) The Author(s) 2018

\begin{abstract}
Imaging spectrometry of non-oceanic aquatic ecosystems has been in development since the late 1980s when the first airborne hyperspectral sensors were deployed over lakes. Most water quality management applications were, however, developed using multispectral mid-spatial resolution satellites or coarse spatial resolution ocean colour satellites till now. This situation is about to change with a suite of upcoming imaging spectrometers being deployed from experimental satellites or from the International Space Station. We review the science of developing applications for inland and coastal aquatic ecosystems
\end{abstract}

C. Giardino

giardino.c@irea.cnr.it

1 CNR-IREA, National Research Council of Italy, Institute for Electromagnetic Sensing of the Environment, 20133 Milan, Italy

2 CNR-ISAC, National Research Council of Italy, Institute of Atmospheric Sciences and Climate, 00133 Rome, Italy

3 Remote Sensing Technology Institute, German Aerospace Center (DLR), Münchener Straße 20, 82234 Weßling, Germany

4 German Aerospace Center (DLR), German Remote Sensing Data Center (DFD), Münchener Straße 20, 82234 Weßling, Germany

5 Bermuda Institute of Ocean Sciences, 17 Biological Station, St. George's GE01, Bermuda

6 Vlaamse Instelling voor Technologisch Onderzoek (VITO), Boeretang 200, 2400 Mol, Belgium

7 Helmholtz-Zentrum Geesthacht, Zentrum für Material- und Küstenforschung GmbH, Max-Planck-Straße 1 I, 21502 Geesthacht, Germany

8 CNR-ISMAR, National Research Council of Italy, Institute of Marine Science, 20133 Venice, Italy

9 Section 1.4 Remote Sensing, Helmholtz Center Potsdam GFZ German Research Center for Geosciences, Telegrafenberg, 14473 Potsdam, Germany

10 International Space Science Institute (ISSI), Hallerstrasse 6, 3012 Bern, Switzerland

11 Climate Lab, University of Bremen, Celsiusstrasse 2 FVG-M2040, 28359 Bremen, Germany

12 Fenner School of Environment and Society, The Australian National University, Building 141, Linnaeus Way, Canberra, ACT 2601, Australia 
that often are a mixture of optically shallow and optically deep waters, with gradients of clear to turbid and oligotrophic to hypertrophic productive waters and with varying bottom visibility with and without macrophytes, macro-algae, benthic micro-algae or corals. As the spaceborne, airborne and in situ optical sensors become increasingly available and appropriate for aquatic ecosystem detection, monitoring and assessment, the science-based applications will need to be further developed to an operational level. The Earth Observation-derived information products will range from more accurate estimates of turbidity and transparency measures, chlorophyll, suspended matter and coloured dissolved organic matter concentration, to more sophisticated products such as particle size distributions, phytoplankton functional types or distinguishing sources of suspended and coloured dissolved matter, estimating water depth and mapping types of heterogeneous substrates. We provide an overview of past science, current state of the art and future directions so that early career scientists as well as aquatic ecosystem managers and associated industry groups may be prepared for the imminent deluge of imaging spectrometry data.

Keywords Inland and coastal water - Imaging spectrometry - Biophysical parameters · Spectral, spatial and temporal resolutions $\cdot$ Satellite observations

\section{Introduction}

Inland and coastal water ecosystems are environmentally important, provide multiple ecosystem services and are vital for human consumption, irrigation, sanitation, transportation, recreation and industry. In the past decades, these ecosystems have experienced high stress from various human impacts as well as climate change (Hartmann et al. 2013). Among them, the increasing eutrophication and pollution of many of these environments are major environmental threats.

There is an increasing need for regular monitoring of inland and coastal waters to support national and international directives and conventions such as the European Water Framework Directive, the US Clean Water Act \& Safe Drinking Water Act and the Australian Reef Water Quality Protection Plan, requiring biological, hydro-morphological and physico-chemical parameters of water bodies to be monitored on a regular basis. Information on the state and development of water bodies is also a prerequisite to meet the United Nations Sustainable Development Goal No. 6 to "ensure availability and sustainable management of water and sanitation for all" by 2020 .

Inland and coastal waters are natural and man-made systems, with differing characteristics that show very large dynamics in time and space. For example, freshwater ecosystems include lakes, ponds, streams and rivers, as well as wetlands, comprised of marshes, mangroves, floodplains and swamps. The overall number of lakes larger than $0.002 \mathrm{~km}^{2}$ is estimated to be more than 117 million making up 3.7\% of the Earth's non-glaciated land area (Verpoorter et al. 2014). However, out of these only a small proportion of water bodies is currently included in a regular and consistent monitoring programme biased towards larger water bodies, whilst the majority of small lakes and water bodies is never monitored.

Earth Observation (EO) may be used for acquiring timely, frequent synoptic information, from local to global scales, of inland and coastal waters. EO based measurements of physical and biochemical parameters in these waters mainly rely on the interpretation of the spectral reflectance, which is used to retrieve water components, water depth and bottom properties. EO data have been successfully applied for mapping inland and coastal 
waters for about 50 years (e.g., Strong 1974; Wang and Shi 2008; Stumpf et al. 2012; Bresciani et al. 2014; Matthews and Odermatt 2015). Landsat data have been continuously used to have long-term lake water quality information on synoptic scale (Olmanson et al. 2008), while for large water bodies many applications used coarse spatial resolution data gathered from of ocean colour satellite sensors because they provide the most suited spectral, radiometric and temporal resolutions for aquatic resolution. In particular, MERIS ocean colour sensor, with its spatial resolution of about $300 \mathrm{~m}$ and dedicated spectral bands for detecting chlorophyll-a (Chl-a) in turbid waters, has been successfully used for studying lakes and coastal waters from 2002 to 2012 (Odermatt et al. 2012). These studies focused on the retrieval of water reflectance, physical parameters (e.g., turbidity, diffuse attenuation coefficient, water clarity), suspended and dissolved water quality components such as Chl-a concentration (commonly used as a proxy of phytoplankton biomass), coloured dissolved organic matter (CDOM) and total suspended matter (TSM). More recently, the synoptic, fine-scale and high-frequency retrieval of these parameters has become possible because of the latest generation of medium to high spatial resolution multispectral sensors onboard Landsat- 8 and Sentinel-2 satellites. These land imaging sensors are not specifically designed for observing aquatic ecosystems but they are suitable for detailed water quality analysis (Pahlevan et al. 2014; Toming et al. 2016) due to their: (1) radiometric sensitivity (>12-bit quantisation) (Hedley et al. 2012; Dörnhöfer and Oppelt 2016); (2) spatial resolution of 10-30 m; (3) revisit times of 16 and 5 days, respectively; and (4) improved spectral band setting in the visible/near-infrared wavelengths range. Successful examples of the use of these new sensors are provided by Hedley et al. (2016) for mapping corals, Kutser et al. (2016) and Giardino et al. (2014) for boreal and subalpine lakes, Dörnhöfer et al. (2016) for oligotrophic lakes, Vanhellemont and Ruddick (2014) for coastal turbid waters, Lobo et al. (2015) and Giardino et al. (2017) for rivers and Brando et al. (2015) for river plumes.

Nevertheless, according to Mouw et al. (2015), the current satellite radiometers are designed for observing the global ocean or land surface and thus not specifically suited for observing coastal and inland waters, so that deriving coastal and inland aquatic applications from these existing sensors remains challenging. Tyler et al. (2016) reviewed the developments and technological advances in EO for the assessment and monitoring of inland, transitional, coastal and shelf-sea waters. They summarised the opportunities that the next generation of satellites offer for water quality monitoring and concluded that the operational use of satellites for the assessment and monitoring of freshwater and coastal ecosystems is still evolving. Muller-Karger et al. (2018) recently outlined specifications for satellite requirements that offer the potential for rapid, frequently repeated, and consistent high-quality observations to characterise changes of essential biodiversity variables of coastal ecosystems.

Most of the challenges in inland and coastal water observations are due to their optical complexity. These aquatic ecosystems can be a mixture of optically shallow and optically deep waters, with gradients of clear to turbid and oligotrophic to hypertrophic productive waters and varying bottom visibility with and without macrophytes. For example, a lake receives and recycles organic and inorganic substances from within the lake, from its watershed and beyond (atmospheric deposition). Hence, a large range in optical absorption and backscattering resulting in high optical variability can be found among and within lakes, estuaries and coastal waters. This poses a challenge for biooptical algorithms applied to optical remote sensing for water quality monitoring applications. Another challenge is performing atmospheric corrections over such variable aquatic ecosystems as their complexity requires different approaches than those for land and ocean applications. 
The effect of the atmosphere on the signal received by EO satellite sensors is significant and usually represents $80 \%$ or more of the total at-sensor radiance, especially in the shorter (blue) wavelengths. Accurate modelling of atmospheric absorption and scattering effects, in addition to the specular water surface reflection effects, is required to derive the water leaving reflectance from hyperspectral image data of water (Gao et al. 2009). Moses et al. (2017) indicated further issues that make the estimation of water leaving reflectance at the surface challenging: (1) the proximity to terrestrial sources of atmospheric pollution which results in an optically heterogeneous atmosphere that is difficult to model; (2) the adjacency effects from neighbouring land pixels around the water body; and (3) the non-negligible reflectance of water in the near-infrared region due to high sediment concentrations in inland and near-coastal waters preventing the use of atmospheric correction schemes adopted for oceans.

Despite the complexity of using imaging spectrometry for inland and coastal water ecosystems monitoring, Hestir et al. (2015) showed how bio-optical algorithms, specifically developed for assessing water quality in optically complex water systems, perform best if they can make use of hyperspectral data. Hyperspectral remote sensing, or imaging spectrometry, provides measurements across numerous discrete narrow bands, forming a contiguous spectrum that enables detection and identification of key biophysical properties of water column and bottom. For over three decades, the acquisition of the contiguous spectrum for each image pixel has been illustrated in the form of hypercubes that are commonly used to illustrate the concept of hyperspectral imaging. In the case of inland and coastal waters applications, hypercubes (Fig. 1) show an amount hyperspectral bands bringing data from the water systems that compared to land targets are mostly limited to the first part of the spectrum. Between 400 and $800 \mathrm{~nm}$, Lee et al. (2007) suggested a minimum of 17 spectral bands to observe subtle changes in the remote sensing reflectance of water, given the high variability in the influence of turbidity, bottom reflectance, and complex atmospheric conditions. Furthermore, when also considering interdisciplinary studies to identify shorelines, floating substances and benthic or emergent communities the required number and range of bands increases substantially. Overall, work is still required on the development and validation of remote sensing algorithms for these optically complex waters (Tyler et al. 2016) for which the large ranges of concentrations of water components (e.g., in Eleveld et al. (2017), Chl-a varies from 0.1 to $940 \mathrm{mg} \mathrm{m}^{-3}$, the TSM from 0.1 to $290 \mathrm{~g} \mathrm{~m}^{-3}$, and the absorption CDOM at $440 \mathrm{~nm}$ from 0.04 to $10 \mathrm{~m}^{-1}$ ), also affect algorithm performances.
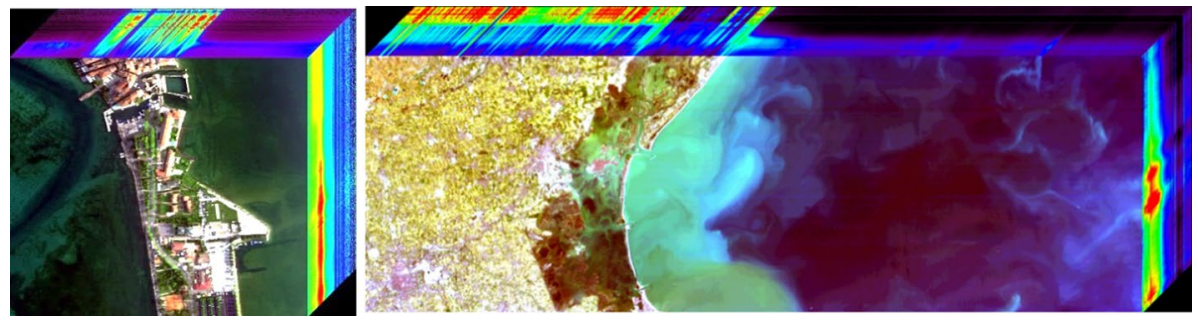

Fig. 1 Imaging spectrometer data hypercubes, where colours in the third dimension represent the reflectance of the edge pixels. On the left the fine-scale details in shallow waters (Sirmione Penisula, Lake Garda) captured from airborne AISA Eagle data; on the right the optical complexity from transitional to coastal and pelagic waters seen from the HICO (Venice lagoon and North Adriatic Sea) onboard the International Space Station 
This study aims to present the fundamentals, state of the art, benefits and limitations as well as future perspectives of imaging spectrometry of inland and coastal water monitoring building forth on the review on aquatic ecosystem from both airborne imaging spectrometry by, e.g., Dekker et al. (2001) and satellite technologies (e.g., Mouw et al. 2015; Bracher et al. 2017). The paper is divided into three sections: Sect. 2 presents the principles of imaging spectrometry and the underpinning bio-optical models that enables simulation and inversion of the concentration of water constituents, water physical properties (turbidity, transparency and vertical attenuation of light), and in the case of optically shallow waters the water depth and bottom type and cover.

Section 3 summarises the main achievements of imaging spectrometry for the study of optically deep and optically shallow waters. Section 4 considers current imaging spectrometry capabilities and future directions based on user requirements, state-of-the-art science as well as remaining challenges.

\section{Principles of Imaging Spectrometry of Inland and Coastal Waters}

\subsection{Bio-optical Models}

Natural waters are composed of pure water and various molecules and particles differing in size, shape and chemical composition. Besides inorganic components like salts, quartz sand, clay minerals, metal oxides, and gas bubbles of various sizes, a large variety of living organisms and dead organic material is observed in most open waters. Imaging spectrometry utilises the fact that some constituents affect the spectral composition of the reflected light sufficiently for quantitative determination of these components. If the reflected light is furthermore influenced by the bottom, in so-called optically shallow waters, imaging spectrometry can also be used to determine water depth and classify benthic substrates in the case of clear water.

The equations describing the relationship between the water constituents and the optical properties of a water body are called bio-optical models to acknowledge the omnipresence of biological components (Morel 2001). Such models connect measured quantities such as reflectance or attenuation with concentrations of different types of material present and their optical properties such as the specific absorption or backscattering coefficient. Optical properties depending only on the material are called inherent optical properties (IOPs), while illumination-dependent optical properties are termed apparent optical properties (AOPs) (Preisendorfer 1961). IOPs are additive, but not AOPs, except under certain simplifying conditions. Concentration-normalised IOPs are called specific inherent optical properties (SIOPs) and labelled by a star symbol.

\subsubsection{Inherent Optical Properties}

Bio-optical models group the huge variety of water constituents usually into three classes: coloured dissolved organic matter (CDOM), phytoplankton (phy), and non-algal particles (NAP). Their contributions to the absorption coefficient, $a(\lambda)$, and the backscattering coefficient, $b_{\mathrm{b}}(\lambda)$, of the water body can be expressed as follows:

$$
\begin{gathered}
a(\lambda)=a_{\mathrm{w}}(\lambda)+C_{\mathrm{CDOM}} \times a_{\mathrm{CDOM}}^{*}(\lambda)+C_{\mathrm{phy}} \times a_{\mathrm{phy}}^{*}(\lambda)+C_{\mathrm{NAP}} \times a_{\mathrm{NAP}}^{*}(\lambda) \\
b_{b}(\lambda)=b_{\mathrm{b}, \mathrm{w}}(\lambda)+C_{\mathrm{phy}} \times b_{\mathrm{b}, \mathrm{phy}}^{*}(\lambda)+C_{\mathrm{NAP}} \times b_{\mathrm{b}, \mathrm{NAP}}^{*}(\lambda)
\end{gathered}
$$


where $a_{\mathrm{w}}(\lambda)$ and $b_{\mathrm{b}, \mathrm{w}}(\lambda)$ are the absorption and backscattering coefficients of pure water, respectively. $C_{i}$ is the concentration of class $i, a_{i}^{*}(\lambda)$ its specific absorption coefficient, and $b_{\mathrm{b}, i}^{*}(\lambda)$ its specific backscattering coefficient. CDOM backscattering is negligible, thus it is omitted in Eq. (2.2). The sum of all particulate components is called total suspended mat$\operatorname{ter}(\mathrm{TSM})$.

Examples of absorption and backscattering coefficients are shown in Fig. 2. They represent water types with relatively low concentrations of CDOM, phytoplankton and NAP: $C_{\mathrm{CDOM}}=1 \mathrm{~g} \mathrm{~m}^{-3}, C_{\mathrm{phy}}=5 \mathrm{mg} \mathrm{m}^{-3}, C_{\mathrm{NAP}}=1 \mathrm{~g} \mathrm{~m}^{-3}$. The SIOPs were chosen as follows: $a_{\mathrm{CDOM}}^{*}(\lambda)$ from Eq. (2.3) with $a_{\mathrm{CDOM}}^{*}(380)=0.44 \mathrm{~m}^{2} \mathrm{~g}^{-1}$ and $S=0.014 \mathrm{~nm}^{-1}$, phy are green algae, $a_{\mathrm{NAP}}^{*}(\lambda)$ from Eq. (2.4) with $S_{\mathrm{NAP}}=0.011 \mathrm{~nm}^{-1}, a_{\mathrm{NAP}}^{*}(440)=0.027 \mathrm{~m}^{2} \mathrm{~g}^{-1}$, $b_{\mathrm{b}, N A P}^{*}(555)=0.011 \mathrm{~m}^{2} \mathrm{~g}^{-1}, n=0.75$.

2.1.1.1 Colored Dissolved Organic Matter (CDOM) Light absorption in the blue to yellow wavelengths of inland and coastal waters is frequently dominated by CDOM. It is the coloured dissolved fraction of the water constituents passing a filter with a pore size of $0.2 \mu \mathrm{m}$. Historical names are, besides others, gelbstoff (Kalle 1938) and yellow matter. Most of its compounds are produced during the decay of plant matter and consist of various humic and fulvic acids. Their absorption is mainly caused by aromatic groups with various degrees and types of substitution, including monosubstituted and polysubstituted phenols and various aromatic acids (Korshin et al. 1997). The absorption maxima of these so-called chromophores lie in the UV, for example at 180, 203 and $253 \mathrm{~nm}$ for benzene (Korshin et al. 1997), which is a common aromatic ring structure in humic matter. The longwave tail of their peaks is commonly approximated by an exponential function for wavelengths greater than $300 \mathrm{~nm}$ :

$$
a_{\mathrm{CDOM}}^{*}(\lambda)=a_{\mathrm{CDOM}}^{*} \times \exp \left\{-S \times\left(\lambda-\lambda_{0}\right)\right\}
$$

The specific absorption coefficient of CDOM, $a_{\mathrm{CDOM}}^{*}$, depends on its composition and is highly variable within a reported range from 0.27 to $2.16 \mathrm{~m}^{2} \mathrm{~g}^{-1}$ at $\lambda_{0}=380 \mathrm{~nm}$ (Sipelgas et al. 2003). The mass-specific concentration of CDOM is rarely measured together with CDOM absorption. Because it is linked to remote sensing data only indirectly, the absorption coefficient at a reference wavelength $\lambda_{0}$ is frequently used to express CDOM concentration, which is a common observable of field measurements and directly linked to the optical properties of water. For $\lambda_{0}=440 \mathrm{~nm}$, CDOM absorption ranges from $\sim 0.004$ to $4 \mathrm{~m}^{-1}$ in coastal areas and from $\sim 0.06$ to $19 \mathrm{~m}^{-1}$ in inland waters (Kirk 2011). The slope $S$ depends on CDOM composition. Values ranging from 0.004 to $0.053 \mathrm{~nm}^{-1}$ were observed
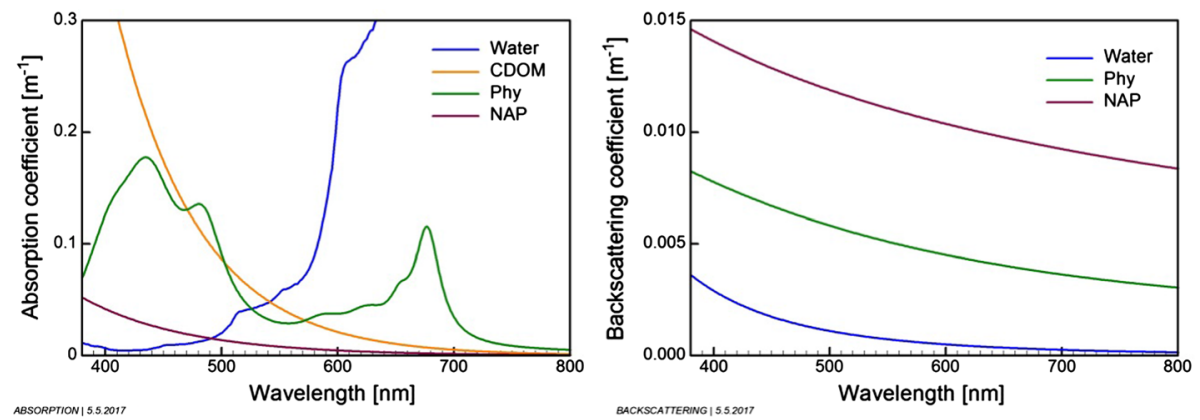

Fig. 2 Examples of absorption (left) and backscattering (right) coefficients of water, CDOM, phytoplankton (Phy) and non-algal particles (NAP) 
(Aas 2000), but in most cases $S$ is in the range between $0.010 \mathrm{~nm}^{-1}$ for humic acid dominated waters and $0.020 \mathrm{~nm}^{-1}$ when fulvic acids prevail (Bricaud et al. 1981; Zepp and Schlotzhauer 1981; Carder et al. 1989; Dekker and Peters 1993; Schwarz et al. 2002; Babin et al. 2003b; Laanen 2007; Binding et al. 2008; Kirk 2011).

Since Eq. (2.3) is an approximation to a function with a maximum in the UV, the slope $S$ decreases with increasing $\lambda_{0}$. Gege (2000) has derived an equation for the dependence of $S$ on $\lambda_{0}$, and he studied the accuracy of the approximation (2.3) for Lake Constance. The error exceeded $10 \%$ for $\left|\lambda-\lambda_{0}\right|>60 \mathrm{~nm}$. As CDOM dominates absorption in many coastal and inland waters, an accurate spectral model of $a_{\mathrm{CDOM}}^{*}(\lambda)$ is important. Scattering of CDOM is small and commonly ignored, yet fluorescence may be significant and should be accounted for at high concentrations (Pozdnyakov et al. 2002). CDOM fluorescence is, however, not well studied.

2.1.1.2 Phytoplankton Phytoplankton is one of the most important water constituents for many aquatic disciplines. Its "fingerprint molecule" Chl-a is frequently used as a measure of concentration since it is an inevitable molecule in the photosynthesis process and present in all species. Natural waters can contain dozens or hundreds of species, most of them with similar optical properties. Perhaps the first optical classification for integration into a bio-optical model was made for Lake Constance (Gege 1998). Four spectral classes could be distinguished (Cryptophyta, Diatoms, Chlorophyte, Dinoflagellates) and their concentrations determined if these were above certain thresholds. A focus of remote sensing applications is currently on phytoplankton functional types (PFTs) (Sathyendranath et al. 2014; Mouw et al. 2017), each PFT representing a group of species aggregated according to distinct functional characteristics, in order to increase our understanding of the role of phytoplankton in the global carbon cycle (Nair et al. 2008).

Except for blooms and certain species, phytoplankton backscattering is often small compared to NAP and has a similar spectral signature (see Fig. 2), thus phytoplankton and NAP backscattering are frequently combined neglecting spectral differences. A detailed description of bio-optical properties of phytoplankton is available in Matthews (2017).

\subsubsection{Non-algal Particles (NAP) All natural waters contain high numbers of mineral} particles derived from the land or from bottom sediments, but also organic components like bacteria, dead cells and fragments of cells (Kirk 2011). As the particles are of various origins, the spectral properties of NAP can change significantly. Nevertheless, useful approximations have been found for both absorption and scattering.

NAP absorption frequently follows an exponential equation similar to CDOM absorption,

$$
a_{\mathrm{NAP}}^{*}(\lambda)=a_{\mathrm{NAP}}^{*}\left(\lambda_{0}\right) \times \exp \left\{-S_{\mathrm{NAP}} \times\left(\lambda-\lambda_{0}\right)\right\}
$$

with a spectral slope typically less than for CDOM. The spectrum sometimes shows shoulders due to the breakdown products of photosynthetic pigments (Kirk 2011). Studies in coastal waters report $S_{\mathrm{NAP}}$ values of $0.0123 \pm 0.0013 \mathrm{~nm}^{-1}$ (Babin et al. 2003b) and $0.011 \mathrm{~nm}^{-1}$ (D'Sa et al. 2006), and $a_{\mathrm{NAP}}^{*}\left(\lambda_{0}\right)$ in the order of $0.027 \mathrm{~m}^{2} \mathrm{~g}^{-1}$ at $\lambda_{0}=440 \mathrm{~nm}$ (Babin et al. 2003b).

The particle size distribution is roughly hyperbolic in many waters (Bader, 1970), i.e. the number of particles with a diameter greater than $D$ is proportional to $D^{-\gamma}$, where $\gamma$ varies widely from 0.7 to 6 (Jerlov 1976). Although small particles are numerous, their low scattering efficiency makes scattering in natural waters frequently dominated by particles 
with $D>2 \mu \mathrm{m}$ (Jerlov 1976). Scattering and backscattering follow approximately the law of Angström:

$$
b_{b, N A P}^{*}(\lambda)=b_{b, N A P}^{*}\left(\lambda_{s}\right) \times\left(\frac{\lambda}{\lambda_{s}}\right)^{-n}
$$

The Angström exponent $n$ is typically between 0 and 1 in the open ocean and in clear coastal waters (Morel and Maritorena 2001; Blondeau-Patissier et al. 2009), and around zero in shallow and inland waters (Babin et al. 2003a; Chami et al. 2005). The specific backscattering coefficient $b_{\mathrm{b}, \mathrm{NAP}}^{*}\left(\lambda_{\mathrm{s}}\right)$ varies by an order of magnitude or more (Chami et al. 2005; Antoine et al. 2011) and is in the order of $0.01 \mathrm{~m}^{2} \mathrm{~g}^{-1}$.

\subsubsection{AOPs for Optically Deep Waters}

Regions of coastal and inland waters that are not noticeably affected by light reflected at the sea floor are called optically deep. The reflected light depends on the optical properties of the water body, but also on the illumination conditions, on the field of view of the sensor and on sensor orientation. That means reflectance is an AOP. To account for different illumination and viewing geometries, various definitions of reflectance exist (Schaepman-Strub et al. 2006). Most useful for remote sensing is radiance reflectance,

$$
r_{\mathrm{rs}}(\lambda)=\frac{L_{\mathrm{u}}(\lambda)}{E_{\mathrm{d}}(\lambda)}\left[s r^{-1}\right]
$$

since sensors on satellite and aircraft measure upwelling radiances, $L_{\mathrm{u}}$, that are induced by the downwelling irradiance, $E_{\mathrm{d}}$, which is the hemispherical integral of the downwelling radiance.

Ignoring non-solar sources such as bioluminescence, sun-induced fluorescence signals from Chl-a, phycobiliproteins, phaeopigments, CDOM as well as Raman scattering, the upwelling radiance consists of two terms:

$$
L_{\mathrm{u}}(\lambda)=L_{\mathrm{w}}(\lambda)+L_{\mathrm{r}}(\lambda)
$$

The first, the water leaving radiance $L_{\mathrm{w}}$, carries information about the water body, while the second, the reflected sky radiance $L_{\mathrm{r}}$, is radiation from specular reflection of light from the sun, the sky and clouds at the water surface. Only $L_{\mathrm{w}}$ is relevant for bio-optical models of the water body, hence the ratio

$$
R_{\mathrm{rs}}(\lambda)=\frac{L_{\mathrm{w}}(\lambda)}{E_{\mathrm{d}}\left(\lambda, 0^{+}\right)}\left[s r^{-1}\right]
$$

is an important quantity for remote sensing of water bodies. It is called remote sensing reflectance. The symbol $0^{+}$indicates a measurement just above the water surface. The quantity $L_{w}$ cannot be measured directly but has to be derived from a measurement of $L_{\mathrm{u}}$ by subtracting $L_{\mathrm{r}}$. Then, $R_{\mathrm{rs}}$ is related to subsurface $r_{\mathrm{rs}}$ as follows (Mobley 1994; Lee et al. 1998):

$$
R_{r s}(\lambda)=\frac{\zeta \times r_{r s}(\lambda)}{1-\Gamma \times r_{r s}(\lambda)}
$$


where $\zeta \approx 0.52$ is the water-to-air radiance divergence factor, and the denominator with $\Gamma \approx 1.6$ accounts for the effects of internal reflection from water to air. Monte Carlo simulations and analytical models have demonstrated the usefulness of the function

$$
u(\lambda)=\frac{b_{\mathrm{b}}(\lambda)}{a(\lambda)+b_{\mathrm{b}}(\lambda)}
$$

for modelling reflectance of water (Gordon et al. 1975). It allows expressing reflectance as the product of an AOP, $f_{r s}(\lambda)$, and an IOP, $u(\lambda)$ :

$$
r_{r s}^{\text {deep }}(\lambda)=f_{r s}(\lambda) \times u(\lambda) .
$$

The superscript "deep" indicates a measurement of optically deep water. A number of analytical models of the $f_{\mathrm{rs}}$ factor have been derived (overview in Sokoletsky and Shen 2014). Here, the model of Albert is used (Albert and Mobley 2003; Albert 2004):

$$
\begin{aligned}
f_{\mathrm{rs}}(\lambda)= & 0.0512 \times\left(1+4.6659 \times u(\lambda)-7.8387 \times u(\lambda)^{2}+5.4571 \times u(\lambda)^{3}\right) \\
& \times\left(1+\frac{0.1098}{\cos \theta_{\text {sun }}^{\prime}}\right) \times\left(1+\frac{0.4021}{\cos \theta_{\mathrm{v}}^{\prime}}\right) \times\left(1-0.0044 v_{\mathrm{w}}\right) .
\end{aligned}
$$
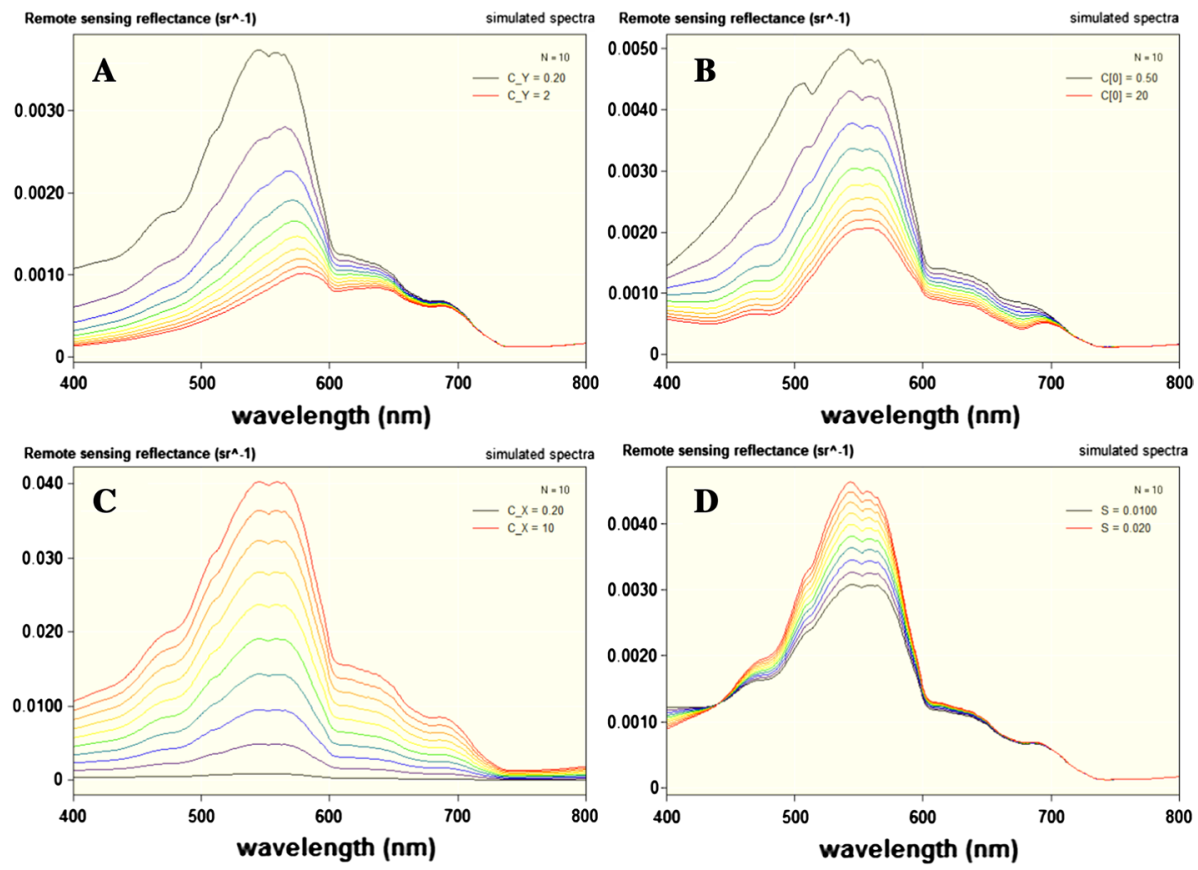

Fig. 3 Variability of remote sensing reflectance of optically deep water. The IOPs of Fig. 2 are used for each simulation. Altered quantities: a CDOM absorption at $440 \mathrm{~nm}$, range $0.2-2 \mathrm{~m}^{-1}$; b phytoplankton concentration, range $0.5-20 \mathrm{mg} \mathrm{m}^{-3}$; $\mathbf{c}$ non-algal particle concentration, range $0.2-10 \mathrm{~g} \mathrm{~m}^{-3}$; $\mathbf{d}$ spectral slope of CDOM absorption, range 0.01-0.02 $\mathrm{nm}^{-1}$. Screenshots of WASI (Gege 2017b). The spacing of the ten lines is equidistant on a linear scale for each plot. Hence the spacing is $0.2 \mathrm{~m}^{-1}$ for Fig. $3 \mathrm{a}, 0.5 \mathrm{mg} \mathrm{m}^{-3}$ for Fig. 3b, $0.2 \mathrm{~g} \mathrm{~m}^{-3}$ for Fig. 3c, and $0.001 \mathrm{~nm}^{-1}$ for Fig. 3d 
Here, $\theta_{\text {sun }}^{\prime}$ is the sun zenith angle in water, $\theta_{\mathrm{v}}^{\prime}$ the viewing zenith angle in water, and $v_{\mathrm{w}}$ the wind speed in units of $\left[\mathrm{m} \mathrm{s}^{-1}\right]$.

These equations allow simulation of $R_{\mathrm{rs}}(\lambda)$ measurements. The variability of $R_{\mathrm{rs}}(\lambda)$ in optically deep waters is illustrated in Fig. 3. The simulations are based on the IOPs shown in Fig. 2 and of concentrations shown in Fig. 3.

\subsubsection{AOPs for Optically Shallow Waters}

When the bottom reflectance signal affects the water leaving radiance, the water is called optically shallow. Analytic models of remote sensing reflectance of such waters have been developed by Lee et al. (1998, 1999) and Albert (Albert and Mobley 2003; Albert 2004). They used the same approach,

$$
\begin{aligned}
r_{\mathrm{rs}}(\lambda)= & r_{\mathrm{rs}}^{\mathrm{deep}}(\lambda) \times\left[1-A_{\mathrm{rs}, 1} \times \exp \left\{-\left(K_{\mathrm{d}}(\lambda)+k_{\mathrm{uW}}(\lambda)\right) \times z_{\mathrm{B}}\right\}\right] \\
& +A_{\mathrm{rs}, 2} \times R_{\mathrm{rs}}^{\mathrm{b}}(\lambda) \times \exp \left\{-\left(K_{\mathrm{d}}(\lambda)+k_{\mathrm{uB}}(\lambda)\right) \times z_{\mathrm{B}}\right\}
\end{aligned}
$$

but different expressions for the model components (see comparisons in Gege 2017a). The first term on the right is the contribution of a water layer of thickness $z_{\mathrm{B}}$, the second term of the bottom. The reflected light has passed the water column twice. The corresponding extinction is described by the attenuation coefficients $K_{\mathrm{d}}$ for downwelling irradiance, $k_{\mathrm{uW}}$ for upwelling radiance originating from the water layer, and $k_{\mathrm{uB}}$ for upwelling radiance from the bottom. $A_{\mathrm{rs}, 1}$ and $A_{\mathrm{rs}, 2}$ are empirical constants close to 1 .

The reflectance properties of the water body bottom (or benthos) are specified by the irradiance reflectance of the bottom, $R^{\mathrm{b}}(\lambda)$. Since the benthos composition and cover type can be heterogeneous on small scales due to mixtures of different benthic substrate type and covers (Fig. 4$), R^{\mathrm{b}}(\lambda)$ is expressed as a weighted sum of the contributions of the different substrates:

$$
R^{\mathrm{b}}(\lambda)=\sum_{n=1}^{N} f_{n} \times A_{n}(\lambda) .
$$
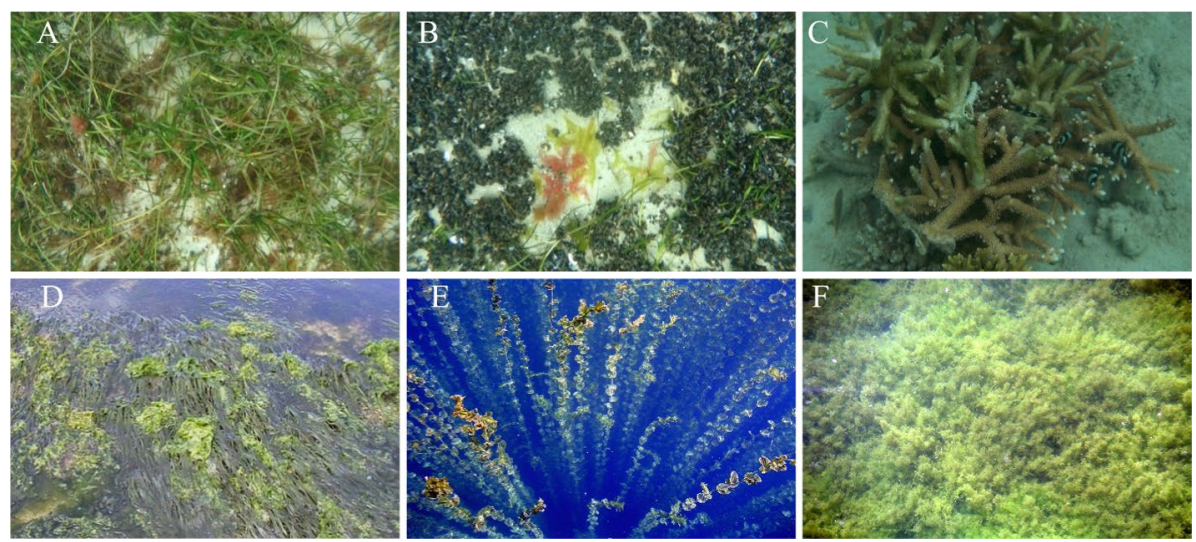

Fig. 4 Heterogeneity of bottom substrates: a seagrass in Baltic Sea; b a mussel bed in Baltic Sea; c a ramified coral of Lampi Island (Myanmar); d seagrass and green algae in South Australia; and submerged macrophytes in Lake Constance (Europe): e Potamogeton sp. and $\mathbf{f}$ Chara tomentosa 


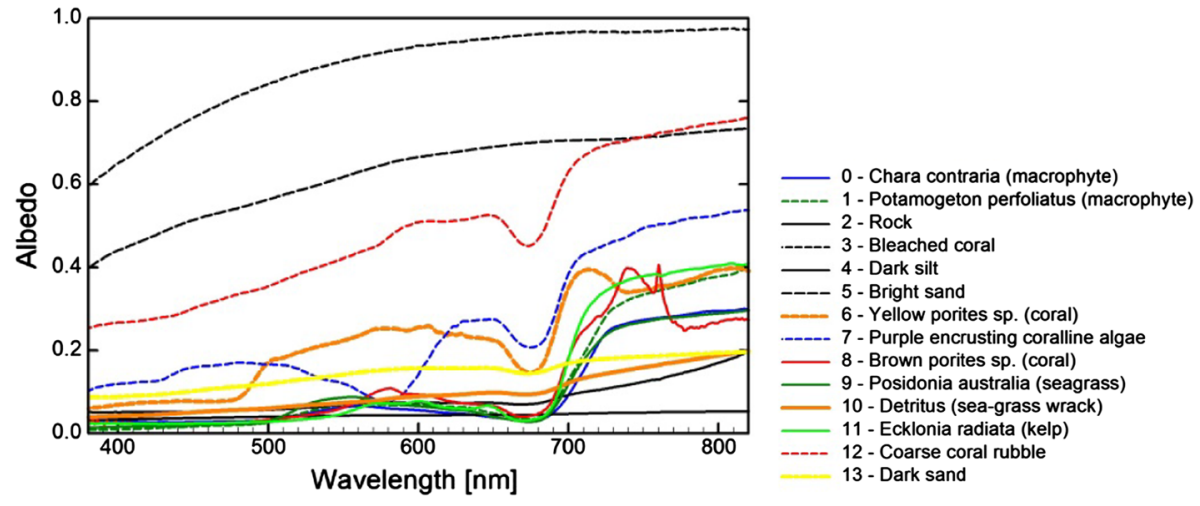

Fig. 5 Spectral variability of bottom substrates (source CEOS 2017)

Irradiance reflectance of a surface is called albedo, thus the symbol $A_{n}(\lambda)$ is used to specify the albedo of substrate number $n$. The weights $f_{n}$ are the areal fractions of the substrates within an image pixel $\left(\Sigma f_{n}=1\right)$. Figure 5 illustrates the diversity of some bottom substrate albedos.
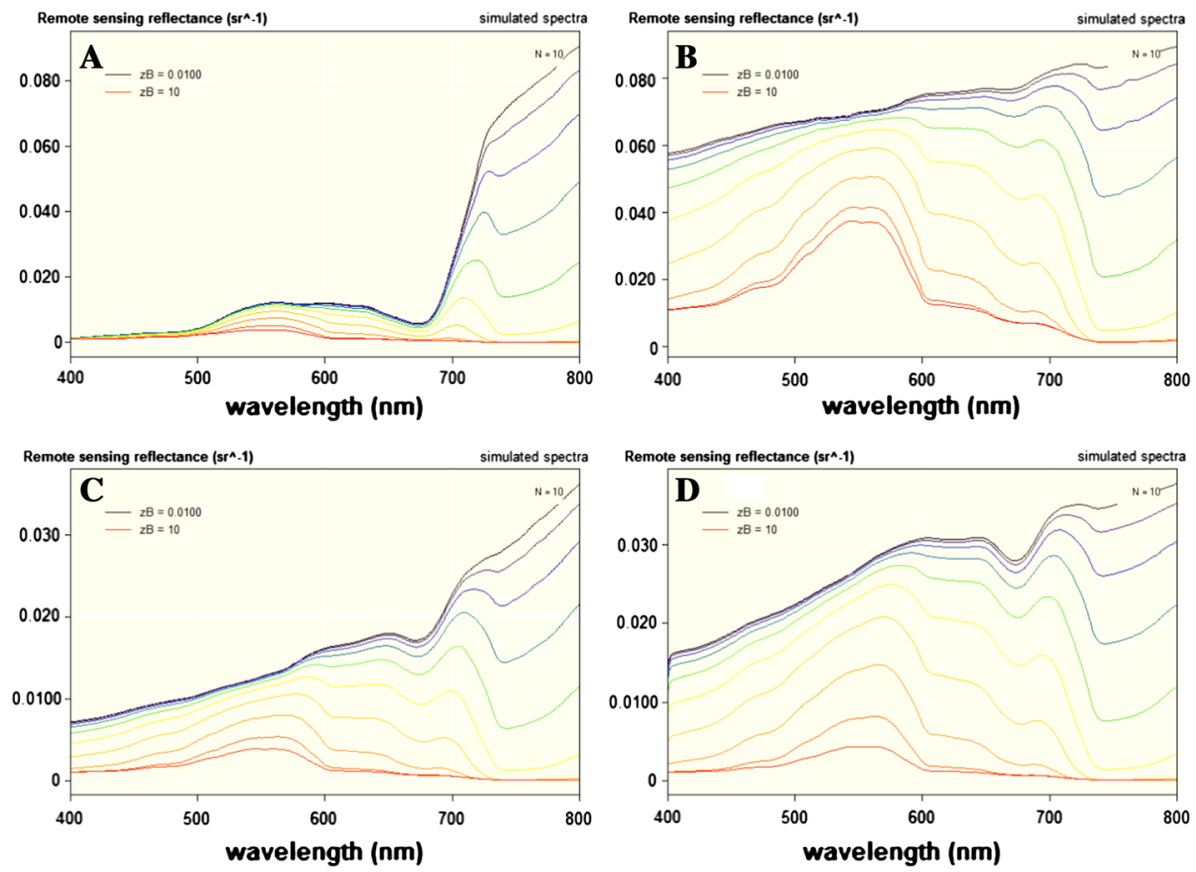

Fig. 6 Dependence of remote sensing reflectance of optically shallow water on water depth and benthos type. Water depth is (from black to red) $0.01,0.02,0.05,0.1,0.2,0.5,1,2,5,10 \mathrm{~m}$. Bottom types are macrophytes (a), dark silt (b), detrital seagrass wrack (c), and dark sand (d). Screenshots of WASI (Gege 2017b) 
The strong dependence of reflectance of optically shallow waters on benthos type and water depth is illustrated in Fig. 6. The albedo spectra 1, 4, 10 and 13 from Fig. 5 were used for the simulations; the water layer was modelled using the IOPs of Fig. 2.

The simulations were made using the software WASI (Gege 2017b) and the Albert model (Albert and Mobley 2003; Albert 2004), which accounts for illumination and viewing geometry and has been developed for a large range of environmental parameters, including most of the water constituent concentrations observed in coastal and inland waters.

\subsection{Retrieval Algorithms}

Various algorithms exist to derive water quality parameters in both optically deep and optically shallow waters based on the relation between remote sensing reflectance, concentration and IOPs of water components, and bottom albedo. The approaches that are used to invert these relations, typically distinguish between empirical and analytical algorithms (Odermatt et al. 2012).

In many applications (e.g., TSM, Turbidity, Chl-a) the concentrations of water components are often retrieved by empirical or semi-empirical algorithms. They make use of single band, band ratio or band difference positioned at wavelengths where remote sensing reflectance is sensitive to variation of water components. The single band algorithms, such as for instance Nechad et al. (2010) for TSM and turbidity, have a sound theoretical background and perform well in a variety of coastal and inland waters; for waters with large variety in concentrations an additional switching has been proposed between several bands at longer wavelengths (Shen et al. 2010; Dogliotti et al. 2015). However, single band algorithms are generally sensitive to the variability in reflectance due to influences of other water constituents, the natural variability in the IOPs and to errors in the atmospheric correction (e.g., Sterckx et al. 2007). To overcome this issue, as well as to account for changes in the concentrations of water constituents and in the spectral shape of their IOPs, several band ratio and band difference models have been proposed for different variables. Gitelson et al. (2007) used band ratios of the value of signal at the secondary Chl-a absorption maximum (at around $675 \mathrm{~nm}$ ) to that at adjacent spectral bands not affected by phytoplankton absorption. These algorithms are typically applicable to Chl-a concentrations above $\sim 10 \mathrm{mg} \mathrm{m}^{-3}$. As the backscattering coefficient has a relatively flat spectral signature, Doxaran et al. (2003) used red-to-green and near-infrared-(NIR)-to-red band ratios for estimating TSM and turbidity. In this case, band ratio algorithms demonstrate reduced effects of variable sediment types and become less sensitive to illumination conditions. Restricted to certain water types in which CDOM dominates absorption in the blue (i.e. high CDOM and low Chl-a) and in which the NIR is not affected much by TSM, CDOM has been estimated with band ratios of blue and NIR bands (Kutser et al. 2005).

Other algorithm approaches are based on the spectral inversion of analytical bio-optical models, such as the one presented in the sections above, and of numerical radiative transfer models (e.g., Hydrolight, Mobley 1994). The models are inverted through neural networks (e.g., Doerffer and Schiller 2007; Schroeder et al. 2007), use of Look Up Tables (Salem et al. 2017), matrix inversion (e.g., Brando and Dekker 2003), quasi-analytical approaches (e.g., Lee et al. 2002) or curve fitting techniques (e.g., Keller 2001) using the different spectral bands available. These approaches provide a robust mechanism for inverting reflectance into IOPs and water quality parameters through a combination of radiative 
transfer theory and a level of empiricism due to the need for "a priori" SIOP parametrisation (Werdell et al. 2013). These approaches are also widely used in shallow waters applications. In this field, most of the state-of-the-art approaches applied to hyperspectral imagery are based on the inversion-optimisation (i.e. curve fitting) of Eq. 2.13 to retrieve simultaneously depth, water quality parameters and $R^{b}(\lambda)$ (see Dekker et al. 2011; Hedley et al. 2016 for comprehensive reviews).

Based on robust physical knowledge, these spectral inversion approaches are more widely applicable than the empirical counterparts, particularly when they are coupled with methods allowing for spatial and temporal variations in water quality parameters typical of optically complex waters (e.g., Moore et al. 2009; Brando et al. 2012; Verpoorter et al. 2012; Eleveld et al. 2017). In particular, these approaches have high potential to work well for hyperspectral remote sensing observations as each single spectrum can be decomposed to estimate IOPs, water quality parameters, bottom types and depth simultaneously.

\subsection{Uncertainties}

An essential question asked by users of remote sensing data is how reliable and accurate are the maps of the distribution of water constituents, water depth and benthic composition, as they are derived from radiance spectra sampled at top of atmosphere or at aircraft altitudes. To answer this question, and by focusing on optically deep waters only, one has to consider a number of issues in optical remote sensing of water optical properties and inwater constituents, which cause and determine the uncertainties:

(1) The radiance spectra, from which concentrations of in-water constituents have been derived are determined by a large number of atmospheric variables, the optical processes at the air/sea interface and by the optical properties of the water. The number of variables that need to be retrieved often exceeds the number of spectral bands available in multispectral Earth observing sensors, thus leading to an underdetermined system. However, in the case of hyperspectral sensors, the number of spectral bands available more than the number of variables to be retrieved. As the optical properties at multiple wavelengths may not be independent of each other, a situation may arise where the inversion system is underdetermined even for hyperspectral observations (depending on the variables to be retrieved). It has to be realised that each of the water components (cf. Section Bio-optical models above) consists of a family of substances with different and varying optical properties, which implies a possible large uncertainty when these components are decomposed from the radiance spectrum observed by the sensor spectrum (but this will depend on whether the representativity of the model complexity and its parametrisation are adequate). Thus, there will always be a level of uncertainty and end-users want to know this level of uncertainty in the final information products to determine if they are fit for purpose.

(2) Water bodies belong to the darkest surfaces of the Earth. In such waters, the fraction of reflected light is very small, being of the order of $1 \%$ of the incident flux. Thus, we have to deal with a low signal-to-noise-ratio (SNR), which requires more accurate correction for the atmospheric and air-water interface contributions (Moses et al. 2017). This signal/noise ratio is wavelength dependent and changes with the concentration of the water constituents, the sky and sunlight reflected at the water surface, the composition of the atmosphere and the sensitivity of the EO sensors. 
(3) The impact of each component of the water constituents on the water leaving radiance spectra depends on its optical properties (specific absorption and scattering coefficients and fluorescence) and its concentration. If one component, e.g., CDOM, dominates the other components it may fully mask the impact of the other components on the reflectance spectrum (masking effect), so that it may become impossible to detect the presence or determine the concentration of the other components (e.g., phytoplankton Chl-a) with the required accuracy.

Other major issues are the nonlinear relationship between the concentration of a water constituent and reflectance. High concentrations of highly-scattering substances might cause saturation, i.e. the reflectance does not increase significantly with increasing concentration. Also, the vertical distribution of the depth of the retrieved signal can lead to significant uncertainties. For multiband and hyperspectral algorithms, one has to consider that each band has a different penetration signal depth, i.e. the depth from which $90 \%$ of the reflected light comes (Gordon and McCluney 1975). This is, among other things, due to the absorption by pure water with its strong increase in the red and near-infrared spectral range. The consequence is that in case of a heterogeneous vertical distribution of the water constituents the spectral bands of a multiband algorithm get information from different layers and would therefore not be consistent with each other.

There are different ways to tackle the issue of uncertainties. The minimum and most important step is to inform the user of EO products about doubtful pixels and possible uncertainties. This requires co-algorithms, which detect cases/pixels, which are contaminated, e.g., by clouds or sun glint or which are out of scope of the algorithm for the atmospheric correction or for the retrieval of water constituents, water depth or benthic composition. These pixels have to be flagged by the co-algorithms as doubtful so that the user can exclude them.

A further step is to estimate the uncertainties. This has to be performed separately for different areas or seasons or even on a pixel by pixel basis because different optical types of waters and different atmospheric conditions cause different problems and thus modify uncertainties in the retrieval process.

If uncertainty numbers are available from comparisons with water samples from different optical water types, an optical classification of the pixels based on their reflectance spectra can be used to determine the uncertainty for each class (Belo Couto et al. 2016; Jackson et al. 2017; Sathyendranath et al. 2017).

In complex waters, where concurrent match-up samples and spectra are rare, the determination of uncertainties might also be based on simulated data. The forward model to simulate the reflectance spectra from the IOPs of water and its constituents obviously must be in agreement with the model of the inversion algorithm and should meet the natural conditions as close as possible. This method has been established for data of MERIS and OLCI of optically complex coastal waters (e.g., Doerffer and Schiller 1997, rev 2016), and for Hyperion by Brando and Dekker (2003) and Giardino et al. (2007). 


\section{Applications and User Requirements}

\subsection{Water Quality Monitoring and Assessment of Biophysical Parameters}

Remote sensing instruments such as spaceborne optical spectrometers provide relevant information to monitor water quality as well as to estimate biophysical parameters. Interested users are both institutional and private. Institutional users include environment agencies, water management authorities and port authorities. Private users include agriculture, forestry, aquaculture, dredging companies and drinking water companies. Fishery and recreation industries are also interested, from the water quality and clarity as well as benthic habitat point of view.

From 1991 (Dekker et al. 1991) till the launch of MODIS in 1999 developments in algorithms for determination of water quality and biophysical properties (reviewed in Dekker et al. 2001) focused on airborne imaging spectrometry, while Landsat and SPOT have been continuously providing data for broader synoptic observation scales (e.g., Lindell et al. 1999; Olmanson et al. 2015) for more than three decades. More recently, the use of medium resolution sensor and of the ocean-coastal-focused MODIS and MERIS (with its successor OLCI) further supported the developments in water quality and biophysical parameter algorithms, while the multispectral Sentinel-2 along with Landsat-8, are offering advanced opportunities for synoptic, fine-scale and high-frequency monitoring applications in lakes (Pahlevan et al. 2014; Toming et al. 2016). Finally, finer scale studies of aquatic ecosystems have been based on higher spatial resolution satellite sensors (e.g., Rapide-Eye, WorldWiew-3) that are attractive for use in spatially heterogeneous areas for applications such as the mapping of benthic habitats (e.g., Paringit and Nadaoka 2012).

In such a context, hyperspectral imaging enables increases in the estimation accuracy of variables currently observed by multispectral sensors (e.g., Chl-a, TSM), as well as facilitates detection of new variables of interest (identification and quantification of particulate and dissolved matter: type and size of suspended particles, types of pigments, organic matter composition, cyanobacteria, inorganic pollutants, etc.) for multiple user-driven applications. For example, some dissolved components are markers of soil erosion while in tropical areas (e.g., Khan et al. 2018); inorganic particulate matter concentration can be used as an indicator of regional (deforestation) and global (climate) changes (e.g., Lal 2003); particulate matter and CDOM may be used as tracers of nutrients or pollutants (e.g., Ylöstalo et al. 2016); CDOM might play a significant role in the global carbon cycle (e.g., Tranvik et al. 2009). Hyperspectral measurements are particularly relevant to assess phytoplankton pigments that provide information for assessing the trophic status, evaluating the ecosystem's functioning and for distinguishing (potentially toxic) harmful algal blooms. For example, Dierssen et al. (2015a) used HICO data to capture a red tide ciliate bloom in coastal waters.

Related to the last case, the following example shows the mapping of phytoplankton types in inland waters. The approach presented in this study makes use of the spectral decomposition of phytoplankton absorption spectra as part of the bio-optical modelling of reflectance. This method allows to obtain information on the major phytoplankton functional types (PFT) present also under non-bloom conditions. The proposed methods, along with the difference in spectral absorption and scattering associated with phytoplankton types also considers the impact of their abundance as changes in phytoplankton quantity (e.g., Chl-a concentration) produce a shift in water reflectance peaks and dips, which only hyperspectral sensors are able to capture. According to different work (Nair et al. 2008; 
Bracher et al. 2009; Sadeghi et al. 2012; Sathyendranath et al. 2014; Mouw et al. 2017) such methods have great potential for hyperspectral remote sensing. Airborne Prism Experiment (APEX) imagery (98 channels used from 426 to $905 \mathrm{~nm}$ ) acquired on 27 September 2014 and corrected for atmosphere and air/water interface effects (Sterckx et al. 2011) was used for mapping PFT in Mantua Lakes in northern Italy. The airborne campaign was developed with coincident field measurements for validation. The Mantua Lakes are small, highly productive and hypertrophic. The lakes show covariant water constituents and transition from fluvial to lentic waters presenting a challenging case for both algorithm development and testing. More than 40 days of in situ measurements were performed in Mantua Lakes over 10 years to achieve a comprehensive dataset of concentrations of water quality parameters, of IOPs and AOPs (Bresciani et al. 2013; Manzo et al. 2015), leading to the parameterisation of a bio-optical model similar to the one described in Sect. 2 or to previously published case-2 models (e.g., Pierson and Strömbeck 2001; Albert and Mobley 2003). In particular, to model the absorption of phytoplankton, the decomposition approach described in Sect. 2 was adopted according with the four following phytoplankton groups: diatoms, chlorophyte, chrysophyta, cryptophyta and cyanophytes (Planktothrix sp. a cyanobacteria species dominated by phycoerythrin pigments, and Cylindrospermopsis raciborskii and Anabaena sp. a cyanobacteria species dominated by phycocyanin).

The bio-optical model was applied to the water reflectance from APEX imagery and all its contiguous bands were selected to estimate Chl-a concentrations and all of each PFT. A collection of input APEX spectra is presented in Fig. 7, illustrating the appearance and shift of spectral peaks and dips. This behaviour is not only due to the specific absorption of phytoplankton pigments but also to the abundance of other water components (TSM and CDOM). In particular, in the spectral region between 670 and $720 \mathrm{~nm}$ the relative Rrs maximum occurs in wavelength positions shifting from $693 \mathrm{~nm}$ to $709 \mathrm{~nm}$, while the position of the reflectance minimum also $667 \mathrm{~nm}$ and $678 \mathrm{~nm}$. These well-known features (Schalles

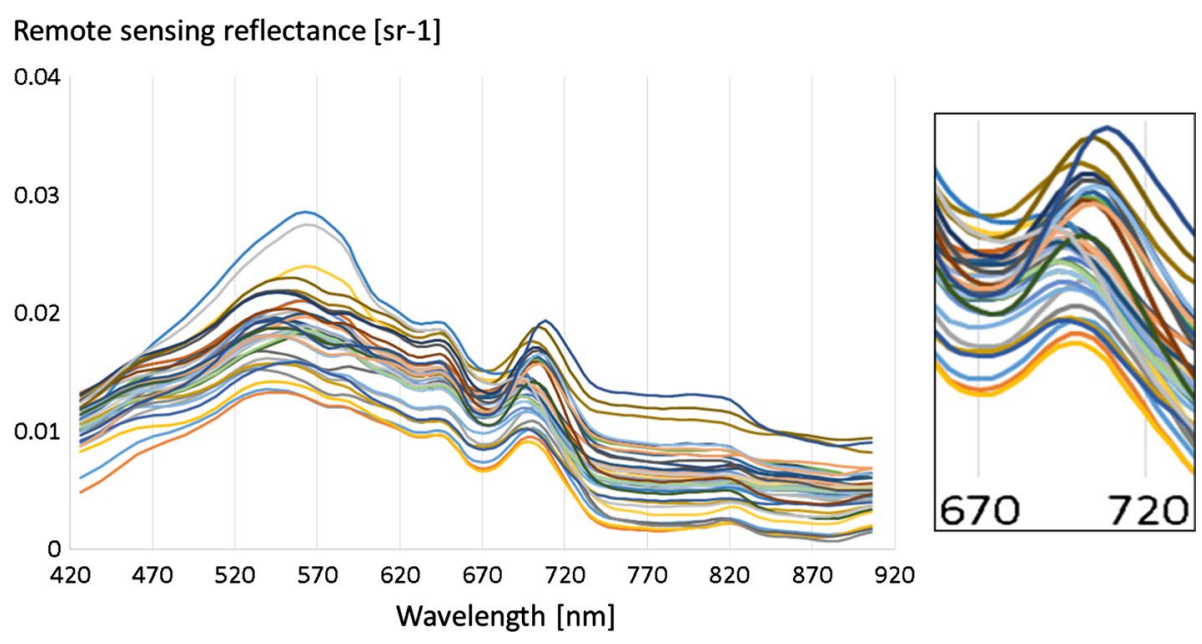

Fig. 7 APEX spectra (corrected for atmosphere and air/water interface effects) from Mantua Lakes, Italy, flown on the 27 September 2014. In the near-infrared region the wavelength position of the relative Rrs maximum shifts from 693 to $709 \mathrm{~nm}$ depending on Chl-a concentration (broadening the 676 in vivo absorption feature) and the biomass of phytoplankton that causes increased scattering, all superimposed on a minimum in combined CDOM, NAP and pure water absorption). On the hand, the position of the reflectance minimum also shifts between 667 and $678 \mathrm{~nm}$ due to the Sun-induced Chl-a fluorescence signal 

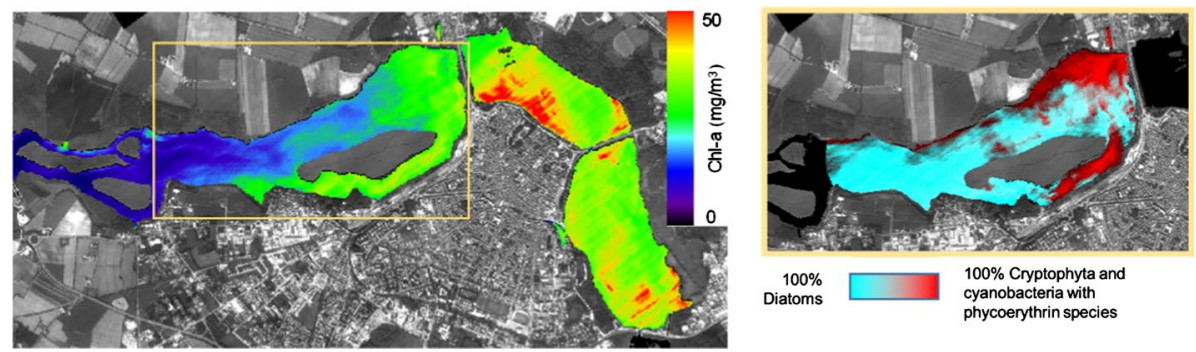

Fig. 8 APEX data from Mantua Lakes, Italy, flown on the 27 September 2014. The map on the left shows the Chl-a concentrations obtained from the inversion of the bio-optical model. The same inversion provided, for the largest lake (yellow box), the distribution of phytoplankton types

and Yacobi 2000; Dall'Olmo and Gitelson 2005) are explained by an increase in Chl-a concentration and the biomass of phytoplankton and by the Sun-induced Chl-a fluorescence signal, that shifts the reflectance minimum towards shorter wavelengths (Dall'Olmo and Gitelson 2005). Therefore, Chl-a concentration is better estimated if contiguous bands are present allowing the switching between the different wavelengths (to capture the relative maximum/minimum of Rrs) or wavelength combinations are feasible (Bresciani et al. 2013). As found Dekker et al. (1991) and Dekker (1993) some spectra also show features due to phycoerythrin and phycocyanin pigments absorption around $590 \mathrm{~nm}$ and $620 \mathrm{~nm}$, respectively, which can potentially be used to distinguish phytoplankton types (Hunter et al. 2016).

Figure 8 shows the output of the bio-optical model inversion. The Chl-a map (Fig. 8, on left) shows a gradient of increasing concentrations from $10 \mathrm{mg} \mathrm{m}^{-3}$ to $50 \mathrm{mg} \mathrm{m}^{-3}$ moving from west to east, thus from river inflow towards the lakes. The accuracy of this map, after the comparisons with water samples taken at nine stations across the three lakes, is high (average in situ: $24.9 \mathrm{mg} \mathrm{m}^{-3}$; average from APEX: $25.2 \mathrm{mg} \mathrm{m}^{-3}, \mathrm{r}^{2}$ of 0.94). For the largest lake, a map of PFT was also produced by combining the algal pigments products obtained for the principal species measured in summer 2014. The PFT map (Fig. 8, on right) shows a west-to-east transition of phytoplankton types, so that diatoms are decreasing for a corresponding increasing of chrysophyta (Chrysochromulina sp.), cryptophyta and Planktothrix sp. a cyanobacteria species sometimes dominated by phycoerythrin (PE) and sometimes by phycocyanin (Dekker 1993). Such a behaviour was also observed in field visits as in the western station the diatoms count was 15,750 cells $/ \mathrm{mL}$, (so representing $66 \%$ of the total phytoplankton population), while in the eastern part of the lake, cryptophyta and Planktothrix sp. count was 18,500 cells/mL (so representing $68 \%$ of the total phytoplankton population while diatoms accounted to $25 \%$ ).

\subsection{Mapping of Shallow Water Habitats}

Remote sensing offers a practical means of regularly mapping and monitoring optically shallow waters (those where the bottom is visible from the water surface and measurably influences the remote sensing reflectance, (Dekker et al. 2011)), which include inland waters, estuarine, tropical coral reef and temperate coastal ecosystems. In particular, 
information in the form of maps of bottom depth and benthic community are needed for science, resource management and defence operations.

EO has been used since the early $1990 \mathrm{~s}$ for mapping of bottom types and benthic communities (e.g., mud, sand-mud mixture, coral sands, coral reefs, seagrass, macrophytes): a thorough review of state of the art and future perspectives of remote sensing of aquatic macrophytes is given by Malthus (2017), while a recent review of remote sensing approaches of coral reefs mapping is provided by Hedley et al. (2016). With a spatial resolution of 10-30 m (up to 2-5 m from WorldView-like sensors) multispectral sensors are ideal for most of the application scales but they are limited to identify species with distinctively different spectral characteristics (e.g., Dekker et al. 2005; Villa et al. 2014). Imaging spectrometry provides the ability to differentiate submerged vegetation and coral reef taxa (Hedley et al. 2012; Botha et al. 2013) thus enabling several applications including fine tracking of biodiversity (Muller-Karger et al. 2018) as well as identification of invasive and resident species (Hestir et al. 2008). Then, Lee et al. (2013), also demonstrated that if WorldView band setting might be used for assessing depths lower than $5 \mathrm{~m}$, then hyperspectral setting is needed for bottom depth mapping at improved accuracy, particularly for waters deeper than $10 \mathrm{~m}$.

In coral reefs, benthic functional types (BFTs, equivalent to PFTs) can be discriminated, based on the presence/absence of diagnostic pigments in the types (Hochberg and Atkinson 2000, 2003; Hochberg et al. 2003b). Corals are host to photosynthetic dinoflagellates (zooxanthellae) which contain peridinin (Jeffrey and Haxo 1968; Prezelin 1987). Other reef algae do not contain peridinin but do have their own identifying pigments (e.g., Table 8.2 in Kirk 2011). Differential spectral absorption by those pigments results in fairly distinct signatures for the fundamental BFTs of coral and algae (Fig. 5). Sand is easily identified by its bright signal, even with fractional coverage by of benthic micro-algae (Roelfsema et al. 2002) present on the surface (Fig. 5).

Coral species cannot be spectrally distinguished (Hochberg et al. 2004) from each other, although Botha et al. (2013) have demonstrated that discriminating different coral colours at higher depth is possible when switching from multispectral to hyperspectral data. In addition to the photosynthetic pigments of the zooxanthellae, many corals possess host pigments, which influence the coral's spectral reflectance (Mazel 1990, 1995, 1996; Salih et al. 2000; Dove et al. 2001; Mazel and Fuchs 2003; Mazel et al. 2003). However, those spectral characteristics are highly variable, even within a single species (Hochberg et al., 2004). As Veron (2000) notes, coral colour is not predictive of taxonomy.

The spectral discrimination between coral and algae need not necessarily rely on fully hyperspectral data (Hochberg and Atkinson 2003). However, greater spectral information does improve the discrimination, while also improving water column correction (Lee and Carder, 2002). At least one near-infrared channel is required for correction of water surface sun and sky glint (Hochberg et al. 2003a; Hedley et al. 2005), and the availability of several channels across the shortwave infrared affords the best possible atmospheric correction (Gao et al., 2000, 2002, 2007).

Along with the challenges of surface effects and water column depth and turbidity, shallow water mapping using remote sensing platforms also includes issues associated with spatial, spectral, and radiometric resolutions. In defining the sensors requirements for inland and coastal water monitoring the needs for substrate mapping are often overlooked (Mouw et al. 2015), although both the CEOS report (2017) and the Muller-Karger et al. (2018) approach (namely H4 imaging), do explicitly deal with these requirements. As an example of trade-off in sensor and mission requirements, NASA's CORAL airborne Earth Venture mission rationale for $8 \mathrm{~m}$ pixels was largely logistical. It was reasoned that $10 \mathrm{~m}$ 

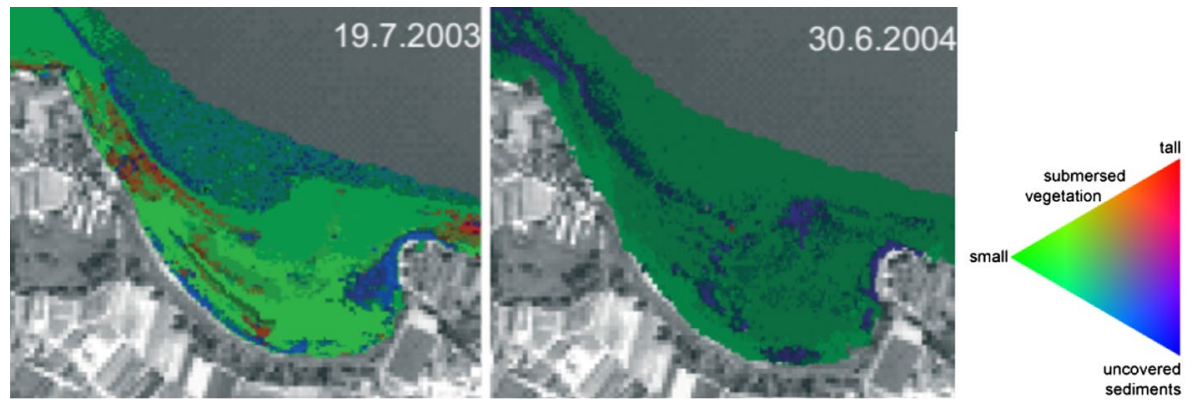

Fig. 9 HyMap data from a Lake Constance (Richenau), flown on 19 July 2003 (left) and 30 June 2004 (right). Classification contains main bottom cover classes of sediment (blue), submersed-small vegetation (green) and emerged-tall vegetation (red). Grey areas in the image are masked as optically deep water areas

or better was required to resolve spatial variability of benthic reef communities. This was based on the science team's collective 9+ decades of experience studying coral reef ecology. At the same time, a survey airplane can only fly above or below commercial air traffic altitudes, $>12,000 \mathrm{~m}$ or $<9000 \mathrm{~m}$, respectively. Flying at $>12,000 \mathrm{~m}$ would result in pixels larger than $10 \mathrm{~m}$. Thus, it was decided to fly at $8500 \mathrm{~m}$, which gave pixels of roughly $8 \mathrm{~m}$.

The following example shows a macrophyte mapping exercise using airborne hyperspectral remote sensing data from HyMAP acquired in July 2003 and June 2004 (Fig. 9). The data were corrected for atmospheric, air-water interface and water body effects using the physical based Modular Inversion Program (MIP) (Heege et al. 2003; Pinnel 2007). The various macrophyte taxa were classified to bottom cover classes by linear spectral unmixing. The result contains main bottom cover classes of submerged growing macrophytes (Characeae) in green, emerged macrophytes (here: mainly Potamogeton perfoliatus and $P$. pectinatus) in red and bottom sediments in blue (see colour triangle in Fig. 9). Mixed picture elements contain more than a single class, e.g., Characeae and bottom sediment. Differentiation of submerged and emerged vegetation could be achieved by subtracting the absolute water depth from the calculated water column on top of the plants. The bottom coverage for the two years could be mapped down to a water depth of $4.5 \mathrm{~m}$, the maximum depth to which plausible reflectance spectra have been derived after water depth correction. The observed changes on benthic communities from July 2001 to June 2004 were mostly detected as an increase in small submersed vegetation further offshore and a reduction of tall vegetation close to shore.

Table 1 Confusion matrix for the classification results of 2003 data

\begin{tabular}{|c|c|c|c|c|c|}
\hline & & \multicolumn{3}{|c|}{ HyMap Classification } & \\
\hline & Vegetation classes & small & tall & uncovered sediments & User's accuracy \\
\hline \multirow{4}{*}{ 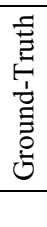 } & small & 56 & 8 & 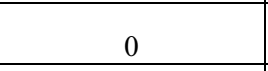 & $87.5 \%$ \\
\hline & tall & 48 & 88 & 1 & $64.2 \%$ \\
\hline & uncovered sediments & 2 & 0 & 13 & $86.7 \%$ \\
\hline & Producer's accuracy & $52.8 \%$ & $91.7 \%$ & $92.9 \%$ & $72.7 \%$ \\
\hline
\end{tabular}


The classification results for 2003 were then validated with extensive ground truth measurements during the flight campaigns and traditional aerial photographic interpretation. The tall- and short-growing macrophytes and sediments were compared to the ground truth data as primary validation step. A plausibility control based on 216 ground truth measurements was statistically analysed. The results (Table 1) indicated a high correspondence $(87.5 \%)$ between short-growing vegetation and sediment $(86.7 \%)$; however, tall-growing macrophytes were less correctly classified (64.2\%), as many of them were misidentified as short-growing macrophytes that had not grown up to the water surface, but were covered with a water column of at least $2 \mathrm{~m}$. An overall accuracy of $73 \%$ was found. However, a spatial resolution of $4 \mathrm{~m}$ pixel might still be a bottleneck for macrophytes species recognition especially in smaller lakes where size and inhomogeneity of the patches require higher spatial information.

\section{Observational Requirements and Future Directions in Imaging Spectrometry}

Developing applications for inland and coastal surface waters, for the water column and for benthos from satellite remote sensing requires high spatial, spectral and temporal resolution and the highest possible radiometric resolution (CEOS 2017; Muller-Karger et al. 2018).

Imaging spectrometry has clear advantages over multispectral sensors for aquatic ecosystem monitoring. For example: a sensor with multiple contiguous spectral bands from blue to near-infrared wavelengths and for very turbid waters also to the short-wave infrared allows switching between the different wavelengths or wavelength combinations where reflectance features are present; a similar sensor is necessary to discriminate phytoplankton types and to assess the concentration of associated pigments, as suggested by Wolanin et al. (2016). Overall, the availability of a contiguous spectrum makes algorithms more effective in a wide variety of waters with varying water column depths and bottom reflectance and lead to more successful inversion of a larger number of properties (Hestir et al. 2015). This combination of factors points to the great utility -effectively a requirement- of hyperspectral data for inland and coastal waters retrievals.

Apart from spectral resolution, spatial resolution is also a key factor to be considered. Medium to high spatial resolution is required for smaller to larger areas (rivers, lakes, lagoons, estuaries, bays) which generally show patchy and inhomogeneous features (Ozesmi and Bauer 2002). In this study, an $8 \mathrm{~m}$ pixel was suggested as trade-off in sensor and mission requirements for regional scale mapping of corals, while a $4 \mathrm{~m}$ pixel would still be a bottleneck for macrophytes species recognition in a small lake.

The temporal resolution depends on the application but it can be critical for monitoring water quality and algal blooms so that data from geostationary platforms might be used to develop improved applications (Huang et al. 2015), while the time of passage can be critical for tides. Finally, a high SNR is also necessary because of the low reflectance by aquatic ecosystems.

In the case of shallow waters, hyperspectral satellite data enables one to identify species, to determine submerged habitat composition and to characterise environmental processes (e.g., macrophyte phenology, coral bleaching). Combined with a high spatial resolution (such as the $8 \mathrm{~m}$ pixel used in regional coral applications described in Sect. 3.2), hyperspectral data might provide species identification in areas characterised by high 
biodiversity. The temporal resolution is probably not critical for applications focused on benthic mapping and inventory while it is critical for tracking processes such as eutrophication and coral bleaching. The acquisition timing is, however, key for intertidal areas.

Further developments in science and applications in imaging spectrometry might be grouped by the platforms from which spectrometers are deployed driving the use of imaging spectrometry in specific applications.

- Field and Near-Surface Imaging Spectrometry Hyperspectral data gathered in the field have been used previously in support of remotely sensed observations (Goetz 2009). In inland and coastal waters they are in particular collected for understanding the link between AOP and quantities defined in the bio-optical models (such IOP), as well as to assist imagery interpretations in terms of reference data or algorithms calibrations (Eleveld et al. 2017). In particular, autonomous ship-based systems provide suitable platforms to collect spatially and temporally diverse continuous field reference data for addressing a minimum required number of spectral matchups for regional validation. A set of hyperspectral radiometer sensors that measure water surface, sky radiance and total irradiance have been successfully mounted to gather reference remote sensing reflectance for validating ocean colour sensors (e.g., Brando et al. 2016; Simis and Olsson 2013). In many cases, the ship-based systems include probes for gathering IOPs and water quality measures (e.g., fluorimeters, turbidimeters and thermometers) relevant for satellite products validation and to and improve the quality assessment of satellite retrievals (Brewin et al. 2016; Liu et al. 2018). Overall, the development in this field is progressing for both EO data processing and for other benefits: allowing the water management authority to apply the same algorithms as used for EO imagery in combination with their in situ sampling programs, continuous measurements (under daylight conditions) and measuring optical properties during time: Bresciani et al. (2013) showcased how continuous autonomous hyperspectral measurements obtained at a mooring are relevant to obtain intra- and inter-daily data in very productive waters for better understanding diurnal processes (e.g., phytoplankton processes such us light adaption, turbidity variations due to tides).

- Airborne Imaging Spectrometry High-resolution airborne hyperspectral sensors (e.g., AVIRIS, AISA, HyMAP, PRISM, APEX) represent enhanced mapping tools, but are limited in spatial coverage and revisit times. These airborne systems provide optimal resolutions for developing inland and water quality applications at fine scale (Dekker et al. 1991; Hoogenboom et al. 1998). In particular, airborne imaging spectrometry has been used to make medium-scale inventories of macrophytes, seagrasses and corals (Heege et al. 2003; Kutser et al. 2006; Hunter et al. 2010). The airborne technology has the merit of providing preliminary tests to design satellite-based systems. For example, Koponen et al. (2001) and Giardino et al. (2005) used airborne AISA and MIVIS images, respectively, for simulating MERIS data on lakes. More recently APEX data have been used to define and validate algorithms for mapping primary producers in eutrophic lake waters (Bolpagni et al. 2014), or to assess atmospheric correction procedures over a small eutrophic lake from the FENIX sensor (Markelin et al. 2016).

- Satellites Imaging Spectrometry Modern spaceborne hyperspectral sensors (e.g., HYPERION, CHRIS-PROBA and HICO from the ISS) show increasing capabilities in inland and coastal water applications (Brando and Dekker 2003; Giardino et al. 2007; Santini et al. 2010; Braga et al. 2013; Dierssen et al. 2015b), although their SNR might be limited in making accurate measurements of moderate changes in water quality parameters (e.g., CDOM with Hyperion in clear lakes (Giardino et al. 2007)). In 
this context, a series of future satellite hyperspectral sensors are progressing showing similar (30 m spatial resolution of the satellite systems EnMAP and PRISMA, and DESIS and HISUI onboard of ISS), and additional (the thermal channels of HyspIRI only) characteristics. These missions will extend the knowledge that so far has been primarily driven by Hyperion with increased spectral and radiometric resolution. They will also allow to make progress in inland and coastal waters applications although, being designed for a variety of applications, might still have some limitations in measuring the remote sensing reflectance (e.g., low) over water bodies. The latter justifies the need for a dedicated atmospheric correction including adjacency effect correction (Sterckx et al. 2011; Moses et al. 2017). More specifically developed for ocean to coastal (optically deep) water applications is PACE (Pre-Aerosol, Cloud, ocean Ecosystem mission), which has been designed to take into account all requirements needed to assess biophysical parameters from space, which range from the atmospheric corrections, to phyto- and CDOM-pigment separation $(5 \mathrm{~nm}$ spectral resolution between 380 and $800 \mathrm{~nm}$, plus a spectral subsampling of $\sim 1$ to $2 \mathrm{~nm}$ resolution from 655 to $710 \mathrm{~nm}$ for refined characterisation of the Chl-a sun-induced fluorescence spectrum). Although designed to study fluorescence of land vegetation, the Earth Explorer ESA Mission FLEX (Fluorescence Explorer) might also have a key role for inland and water quality applications once launched. FLEX is on the same orbit as OLCI on Sentinel-3 and, albeit with a narrower swath, will measure in a narrow and contiguous spectral range of 500-780 nm, which is particular relevant for assessing the accessory pigments of cyanobacteria (phycocyanin and phycoerythrin) as well as Chl fluorescence.

Final recommendations for future directions in imaging spectrometry should also exploit using synergistically different sensor types (hyper- versus multispectral, high spatial versus high temporal resolution) as accurately described in Guanter et al. (in press).

Acknowledgements This paper is an outcome of a workshop on requirements, capabilities and directions in spaceborne imaging spectroscopy held at the International Space Science Institute (ISSI) in Bern, Switzerland, in November 2016. APEX data were provided by EUFAR TA. The activities in Lake Mantua were part of and co-funded by INFORM (Grant Agreement No. 606865) project funded under the European Commission's Seventh Framework Programme (FP7/2007-2013). We are very grateful to Shubha Sathyendranath and to the other anonymous reviewer for their detailed comments that significantly improved the manuscript.

Open Access This article is distributed under the terms of the Creative Commons Attribution 4.0 International License (http://creativecommons.org/licenses/by/4.0/), which permits unrestricted use, distribution, and reproduction in any medium, provided you give appropriate credit to the original author(s) and the source, provide a link to the Creative Commons license, and indicate if changes were made.

\section{References}

Aas E (2000) Spectral slope of yellow substance: problems caused by small particles. In: Proceedings of ocean optics XV conference, October 16-20, 2000, Monaco

Albert A (2004) Inversion technique for optical remote sensing in shallow water. Ph.D. dissertation, Universität Hamburg, Hamburg, Germany, pp 188

Albert A, Mobley CD (2003) An analytical model for subsurface irradiance and remote sensing reflectance in deep and shallow case-2 waters. Opt Express 11:2873-2890 
Antoine D, Siegel DA, Kostadinov T, Maritorena S, Nelson NB, Gentili B, Vellucci V, Guillocheau N (2011) Variability in optical particle backscattering in three contrasting bio-optical oceanic regimes. Limnol Oceanogr 56(3):955-973

Babin M, Morel A, Fournier-Sicre V, Fell F, Stramski D (2003a) Light scattering properties of marine particles in coastal and open ocean waters as related to the particle mass concentration. Limnol Oceanogr 48:843-859

Babin M, Stramski D, Ferrari GM, Claustre H, Bricaud A, Obolensky G et al (2003b) Variations in the light absorption coefficients of phytoplankton, nonalgal particles, and dissolved organic matter in coastal waters around Europe. J Geophys Res 108:C7

Bader H (1970) The hyperbolic distribution of particle sizes. J Geophys Res 75:2822-2830

Belo Couto A, Brotas Mélin F, Groom S, Sathyendranath S (2016) Inter-comparison of OC-CCI chlorophyll-a estimates with precursor data sets. Int J Remote Sens 37(18):4337-4355

Binding CE, Jerome JH, Bukata RP, Booty WG (2008) Spectral absorption properties of dissolved and particulate matter in Lake Erie. Remote Sens Environ 112:1702-1711

Blondeau-Patissier D, Brando VE, Oubelkheir K, Dekker AG, Clementson LA, Daniel P (2009) Bio-optical variability of the absorption and scattering properties of the Queensland inshore and reef waters, Australia. J Geophys Res 114:C05003

Bolpagni R, Bresciani M, Laini A, Pinardi M, Matta E, Ampe EM, Giardino C, Viaroli P, Bartoli M (2014) Remote sensing of phytoplankton-macrophyte coexistence in shallow hypereutrophic fluvial lakes. Hydrobiologia 737(1):67-76

Botha EJ, Brando VE, Anstee JM, Dekker AG, Sagar S (2013) Increased spectral resolution enhances coral detection under varying water conditions. Remote Sens Environ 44:145-163

Bracher A, Vountas M, Dinter T, Burrows JP, Röttgers R, Peeken I (2009) Quantitative observation of cyanobacteria and diatoms from space using PhytoDOAS on SCIAMACHY data. Biogeosciences 6:751-764

Bracher A, Bouman HA, Bricaud A, Brewin RWJ, Brotas V, Ciotti AM, Clementson L, Devred E, Di Cicco AM, Dutkiewicz S, Hardman-Mountford NJ, Hickman AE, Hieronymi M, Hirata T, Losa SN, Mouw CB, Organelli E, Raitsos DE, Uitz J, Vogt M, Wolanin A (2017) Obtaining phytoplankton diversity from ocean color: a scientific roadmap for future development. Frontiers Mar Sci 4:00055

Braga F, Giardino C, Bassani C, Matta E, Candiani G, Strömbeck N, Adamo M, Bresciani M (2013) Assessing water quality in the northern Adriatic Sea from HICO ${ }^{\text {TM }}$ data. Remote Sens Lett 4(10):1028-1037

Brando VE, Dekker AG (2003) Satellite hyperspectral remote sensing for estimating estuarine and coastal water quality. IEEE Trans Geosci Remote 41(6):1378-1387

Brando VE, Dekker AG, Park YJ, Schroeder T (2012) Adaptive semianalytical inversion of ocean color radiometry in optically complex waters. Appl Opt 51(15):2808-2833

Brando VE, Braga F, Zaggia L, Giardino C, Bresciani M, Matta E, Bellafiore D, Ferrarin C, Maicu F, Benetazzo A, Bonaldo D (2015) High-resolution satellite turbidity and sea surface temperature observations of river plume interactions during a significant flood event. Ocean Sci 11(6):909

Brando VE, Lovell JL, King EA, Boadle D, Scott R, Schroeder T (2016) The potential of autonomous ship-borne hyperspectral radiometers for the validation of ocean color radiometry data. Remote Sens $8(2): 150$

Bresciani M, Rossini M, Morabito G, Matta E, Pinardi M, Cogliati S, Julitta T, Colombo R, Braga F, Giardino C (2013) Analysis of within-and between-day chlorophyll-a dynamics in Mantua Superior Lake, with a continuous spectroradiometric measurement. Mar Freshw Res 64(4):303-316

Bresciani M, Adamo M, De Carolis G, Matta E, Pasquariello G, Vaičiūtė D, Giardino C (2014) Monitoring blooms and surface accumulation of cyanobacteria in the Curonian Lagoon by combining MERIS and ASAR data. Remote Sens Environ 146:124-135

Brewin RJ, Dall'Olmo G, Pardo S, van Dongen-Vogels V, Boss ES (2016) Underway spectrophotometry along the Atlantic Meridional Transect reveals high performance in satellite chlorophyll retrievals. Remote Sens Environ 183:82-97

Bricaud A, Morel A, Prieur L (1981) Absorption by dissolved organic matter of the sea (yellow substance) in the UV and visible domains. Limnol Oceanogr 26:43-53

Carder KL, Harvey GR, Ortner PB (1989) Marine humic and fulvic acids: their effects on remote sensing of ocean chlorophyll. Limnol Oceanogr 34:68-81

CEOS (2017) Feasibility study for an aquatic ecosystem earth observing sensor. In: Dekker AG (eds) CEOS report 2017. CSIRO, Canberra

Chami M, Shybanov EB, Churilova TY, Khomenko GA, Lee ME-G, Martynov OV, Berseneva GA, Korotaev GK (2005) Optical properties of the particles in the Crimea coastal waters (Black Sea). J Geophys Res 110:C11020 
D’Sa EJ, Miller RL, Del Castillo C (2006) Bio-optical properties and ocean color algorithms for coastal waters influenced by the Mississippi River during a cold front. Appl Opt 45:7410-7428

Dall'Olmo G, Gitelson AA (2005) Effect of bio-optical parameter variability on the remote estimation of chlorophyll-a concentration in turbid productive waters: experimental results. Appl Opt 44(3):412-422

Dekker AG (1993) Detection of optical water quality parameters for eutrophic waters by high resolution remote sensing, Vrije Universiteit, Amsterdam, pp 1-240. dare.ubvu.vu.nl

Dekker AG, Peters SWM (1993) The use of the Thematic Mapper for the analysis of eutrophic lakes: a case study in The Netherlands. Int J Remote Sens 14:799-822

Dekker AG, Malthus TJ, Seyhan E (1991) Quantitative modeling of inland water quality for high-resolution MSS systems. IEEE Trans Geosci Remote 29(1):89-95

Dekker AG, Brando VE, Anstee JM, Pinnel N, Kutser T, Hoogenboom HJ, Pasterkamp R, Peters SWM, Vos RJ, Olbert C, Malthus TJ (2001) Imaging spectrometry of water, Ch. 11 in: imaging spectrometry: basic principles and prospective applications: remote sensing and digital image processing, $\mathrm{v}$. IV. Kluwer Academic Publishers, Dordrecht, pp 307-359

Dekker AG, Brando VE, Anstee JM (2005) Retrospective seagrass change detection in a shallow coastal tidal Australian lake. Rem Sens Environ 97:415-433

Dekker AG, Phinn SR, Anstee J, Bissett P, Brando VE, Casey B, Fearns P, Hedley J, Klonowski W, Lee ZP, Lynch M (2011) Intercomparison of shallow water bathymetry, hydro-optics, and benthos mapping techniques in Australian and Caribbean coastal environments. Limnol Oceanogr-Meth 9(9):396-425

Dierssen H, McManus GB, Chlus A, Qiu D, Gao BC, Lin S (2015a) Space station image captures a red tide ciliate bloom at high spectral and spatial resolution. Proc Natl Acad Sci 112(48):14783-14787

Dierssen HM, Chlus A, Russell B (2015b) Hyperspectral discrimination of floating mats of seagrass wrack and the macroalgae Sargassum in coastal waters of Greater Florida Bay using airborne remote sensing. Remote Sens Environ 167:247-258

Doerffer R, Schiller H (1997) Pigment index, sediment and gelbstoff retrieval from directional water leaving radiance reflectances using inverse modelling technique, algorithm theoretical basis document (ATBD) ESA Doc. No. PO-TN-MEL-GS-0005

Doerffer R, Schiller H (2007) The MERIS case 2 water algorithm. Int J Remote Sens 28(3-4):517-535

Dogliotti AI, Ruddick KG, Nechad B, Doxaran D, Knaeps E (2015) A single algorithm to retrieve turbidity from remotely-sensed data in all coastal and estuarine waters. Remote Sens Environ 156:157-168

Dörnhöfer K, Oppelt N (2016) Remote sensing for lake research and monitoring-recent advances. Ecol Indic 64:105-122

Dörnhöfer K, Göritz A, Gege P, Pflug B, Oppelt N (2016) Water constituents and water depth retrieval from Sentinel-2a-a first evaluation in an oligotrophic lake. Remote Sens 8(11):941

Dove SG, Hoegh-Guldberg O, Ranganathan S (2001) Major colour patterns of reef-building corals are due to a family of GFP-like proteins. Coral Reefs 19(3):197-204

Doxaran D, Froidefond JM, Castaing P (2003) Remote-sensing reflectance of turbid sediment dominated waters. Reduction of sediment type variations and changing illumination conditions effects by use of reflectance ratios. Appl Opt 42:2623-2634

Eleveld MA, Ruescas AB, Hommersom A, Moore TS, Peters SW, Brockmann C (2017) An optical classification tool for global lake waters. Remote Sens 9(5):420

Gao BC, Montes MJ, Ahmad Z, Davis CO (2000) Atmospheric correction algorithm for hyperspectral remote sensing of ocean color from space. Appl Opt 39(6):887-896

Gao BC, Yang P, Han W, Li RR, Wiscombe WJ (2002) An algorithm using visible and 1.38- $\mu$ m channels to retrieve cirrus cloud reflectances from aircraft and satellite data. IEEE Trans Geosci Remote 40(8):1659-1668

Gao BC, Montes MJ, Li RR, Dierssen HM, Davis CO (2007) An atmospheric correction algorithm for remote sensing of bright coastal waters using MODIS land and ocean channels in the solar spectral region. IEEE Trans Geosci Remote 45(6):1835-1843

Gao BC, Montes MJ, Davis CO, Goetz AFH (2009) Atmospheric correction algorithms for hyperspectral remote sensing data of land and ocean. Remote Sens Environ 113:17-24. https://doi.org/10.1016/j. rse.2007.12.015

Gege P (1998) Characterization of the phytoplankton Lake Constance for classification by remote sensing. In: Bäuerle E, Gaedke U (eds) Lake constance, characterization of an ecosystem in transition, Arch Hydrobiol Spec. Issues Advanc Limnol, vol 53, pp 179-193

Gege P (2000) Gaussian model for yellow substance absorption spectra. In: Proceedings of ocean optics XV conference, October 16-20, 2000, Monaco 
Gege P (2017a) Radiative transfer theory for inland waters. In: Mishra DR, Ogashawara I (eds) Biooptical modelling and remote sensing of inland waters. Elsevier, Amsterdam, pp 27-69. https:// doi.org/10.1016/B978-0-12-804644-9.00002-1

Gege P (2017b) WASI (water colour simulator). http://www.ioccg.org/data/software.html. Accessed 04 Aug 2017

Giardino C, Candiani G, Zilioli E (2005) Detecting chlorophyll-a in Lake Garda using TOA MERIS radiances. Photogramm Eng Rem Sens 71(9):1045-1051

Giardino C, Brando VE, Dekker AG, Strömbeck N, Candiani G (2007) Assessment of water quality in Lake Garda (Italy) using Hyperion. Remote Sens Environ 109(2):183-195

Giardino C, Bresciani M, Cazzaniga I, Schenk K, Rieger P, Braga F, Matta E, Brando VE (2014) Evaluation of multi-resolution satellite sensors for assessing water quality and bottom depth of Lake Garda. Sensors 14(12):24116-24131

Giardino C, Bresciani M, Braga F, Cazzaniga I, De Keukelaere L, Knaeps E, Brando VE (2017) Biooptical modeling of total suspended solids. In: Mishra DR, Ogashawara I (eds) Bio-optical modeling and remote sensing of inland waters. Elsevier, Amsterdam, pp 129-156

Gitelson AA, Schalles JF, Hladik CM (2007) Remote chlorophyll-a retrieval in turbid, productive estuaries: Chesapeake bay case study. Remote Sens Environ 109:464-472

Goetz AF (2009) Three decades of hyperspectral remote sensing of the earth: a personal view. Remote Sens Environ 113:S5-S16

Gordon HR, McCluney WR (1975) Estimation of the depth of sunlight penetration in the sea for remote sensing. Appl Opt 14(2):413-416

Gordon HR, Brown OB, Jacobs MM (1975) Computed relationships between the inherent and apparent optical properties of a flat, homogeneous ocean. Appl Opt 14:417-427

Guanter L, Brell M, C-W Chan J, Giardino C, Gomez-Dans J, Mielke C, Morsdorf F, Segl K, Yokoya N (in press) Synergies of spaceborne imaging spectroscopy with other remote sensing techniques, Surv Geophys

Hartmann DL, Tank AMK, Rusticucci M, Alexander LV, Brönnimann S, Charabi YAR et al (2013) Observations: atmosphere and surface. In: Change Climate (ed) Climate change 2013 the physical science basis: working group I contribution to the fifth assessment report of the intergovernmental panel on climate change. Cambridge University Press, Cambridge

Hedley JD, Harborne AR, Mumby PJ (2005) Simple and robust removal of sun glint for mapping shallowwater benthos. Int J Remote Sens 26(10):2107-2112

Hedley J, Roelfsema C, Koetz B, Phinn S (2012) Capability of the Sentinel 2 mission for tropical coral reef mapping and coral bleaching detection. Remote Sens Environ 120:145-155

Hedley JD, Roelfsema CM, Chollett I, Harborne AR, Heron SF et al (2016) Remote sensing of coral reefs for monitoring and management: a review. Remote Sens 8(2):118

Heege T, Bogner A, Pinnel N (2003) Mapping of submerged aquatic vegetation with a physically based process chain. In: Kramer E (Ed.), Remote sensing of the ocean and sea ice, September 8-12, 2003. SPIE, The International Society for Optical Engineering, vol 5233, Barcelona, Spain

Hestir EL, Khanna S, Andrew ME, Santos MJ, Viers JH, Greenberg JA, Rajapakse SS, Ustin SL (2008) Identification of invasive vegetation using hyperspectral remote sensing in the California Delta ecosystem. Remote Sens Environ 112(11):4034-4047

Hestir EL, Brando VE, Bresciani M, Giardino C, Matta E, Villa P, Dekker AG (2015) Measuring freshwater aquatic ecosystems: the need for a hyperspectral global mapping satellite mission. Remote Sens Environ 167:181-195

Hochberg EJ, Atkinson MJ (2000) Spectral discrimination of coral reef benthic communities. Coral Reefs 19:164-171

Hochberg EJ, Atkinson MJ (2003) Capabilities of remote sensors to classify coral, algae and sand as pure and mixed spectra. Remote Sens Environ 85(2):174-189

Hochberg EJ, Andréfouët S, Tyler MR (2003a) Sea surface correction of high spatial resolution Ikonos images to improve bottom mapping in near-shore environments. IEEE Trans Geosci Remote 41(7):1724-1729

Hochberg EJ, Atkinson MJ, Andréfouët S (2003b) Spectral reflectance of coral reef bottom-types worldwide and implications for coral reef remote sensing. Remote Sens Environ 85:159-173

Hochberg EJ, Atkinson MJ, Apprill A, Andréfouët S (2004) Spectral reflectance of coral. Coral Reefs 23(1):84-95

Hoogenboom HJ, Dekker AG, De Haan JF (1998) Retrieval of chlorophyll and suspended matter in inland waters from CASI data by matrix inversion. Can J Remote Sens 24(2):144-152 
Huang CC, Shi K, Yang H, Li YM, Zhu AX, Sun DY, Xu LJ, Zou J, Chen X (2015) Satellite observation of hourly dynamic characteristics of algae with Geostationary Ocean Color Imager (GOCI) data in Lake Taihu. Remote Sens Environ 159:278-287

Hunter PD, Gilvear DJ, Tyler AN, Willby NJ, Kelly A (2010) Mapping macrophytic vegetation in shallow lakes using the Compact Airborne Spectrographic Imager (CASI). Aquat Conserv 20:717-727

Hunter PD, Matthews MW, Kutser T, Tyler AN (2016) Remote sensing of cyanobacterial blooms in inland, coastal, and ocean waters. Handb Cyanobacterial Monit Cyanotoxin Anal 18:89-99

Jackson T, Sathyendranath S, Melin F (2017) An improved optical classification scheme for the ocean colour essential climate variable and its applications. Remote Sens Environ 203:152-161

Jeffrey S, Haxo F (1968) Photosynthetic pigments of symbiotic dinoflagellates (zooxanthellae) from corals and clams. Biol Bull 135(1):149-165

Jerlov NG (1976) Marine optics, 2nd edn. Elsevier, Amsterdam

Kalle K (1938) Zum Problem der Meereswasserfarbe. Ann Hydrol Mar Mitt 66:1-13

Keller PA (2001) Comparison of two inversion techniques of a semi-analytical model for the determination of lake water constituents using imaging spectrometry data. Sci Total Environ 14(268):189-196

Khan MF, Maulud KNA, Latif MT, Chung JX, Amil N, Alias A, Nadzir MSM, Sahani M, Mohammad M, Jahaya MF, Hassan H (2018) Physicochemical factors and their potential sources inferred from longterm rainfall measurements at an urban and a remote rural site in tropical areas. Sci Total Environ 613:1401-1416

Kirk JTO (2011) Light and photosynthesis in aquatic ecosystems, 3rd edn. Cambridge University Press, New York

Koponen S, Pulliainen J, Servomaa H, Zhang Y, Hallikainen M, Kallio K, Vepsäläinen J, Pyhälahti T, Hannonen T (2001) Analysis on the feasibility of multi-source remote sensing observations for chl-a monitoring in Finnish lakes. Sci Total Environ 268(1-3):95-106

Korshin GV, Chi-Wang L, Benjamin MM (1997) Monitoring the properties of natural organic matter through UV spectroscopy: a consistent theory. Water Res 31:1787-1795

Kutser T, Pierson DC, Kallio KY, Reinart A, Sobek S (2005) Mapping lake CDOM by satellite remote sensing. Remote Sens Environ 94:535-540

Kutser T, Miller I, Jupp DLB (2006) Mapping coral reef benthic substrates using hyperspectral space-borne images and spectral libraries. Estuar Coast Shelf S 70:449-460

Kutser T, Paavel B, Verpoorter C, Ligi M, Soomets T, Toming K, Casal G (2016) Remote sensing of black lakes and using $810 \mathrm{~nm}$ reflectance peak for retrieving water quality parameters of optically complex waters. Remote Sens 8(6):497

Laanen M (2007) Yellow matters-improving the remote sensing of coloured dissolved organic matter in inland freshwaters. Ph.D. dissertation. Vrije Universiteit Amsterdam, pp 267

Lal R (2003) Soil erosion and the global carbon budget. Environ Int 29(4):437-450

Lee Z-P, Carder KL (2002) Effect of spectral band numbers on the retrieval of water column and bottom properties from ocean color data. Appl Opt 41(12):2191-2201

Lee Z-P, Carder KL, Mobley CD, Steward RG, Patch JS (1998) Hyperspectral remote sensing for shallow waters: 1. A semianalytical model. Appl Opt 37:6329-6338

Lee Z-P, Carder KL, Mobley CD, Steward RG, Patch JS (1999) Hyperspectral remote sensing for shallow waters: 2. Deriving bottom depths and water properties by optimization. Appl Opt 38:3831-3843

Lee Z-P, Carder KL, Arnone RA (2002) Deriving inherent optical properties from water color: a multiband quasi-analytical algorithm for optically deep waters. Appl Opt 41:5755-5772

Lee Z-P, Carder KL, Arnone RA, He M (2007) Determination of primary spectral bands for remote sensing of aquatic environments. Sensors 7(12):3428-3441

Lee Z-P, Weidemann A, Arnone R (2013) Combined Effect of reduced band number and increased bandwidth on shallow water remote sensing: the case of worldview 2. IEEE Trans Geosci Remote 51(5):2577-2586

Lindell T, Pierson D, Premazzi G, Zilioli E (1999) Manual for monitoring European lakes using remote sensing techniques. EUR report no.18665 EN. Luxembourg: Office for Official Publications of the European Communities

Liu Y, Roettgers R, Ramírez-Pérez M, Dinter T, Steinmetz F, Noethig E-M, Hellmann S, Wiegmann S, Bracher A (2018) Underway spectrophotometry in the Fram Strait (European Arctic Ocean): a highly resolved chlorophyll a data source for complementing satellite ocean color. Optics Express: ID 313439

Lobo FL, Costa MP, Novo EM (2015) Time-series analysis of Landsat-MSS/TM/OLI images over Amazonian waters impacted by gold mining activities. Remote Sens Environ 157:170-184 
Malthus M (2017) Bio-optical modeling and remote sensing of aquatic macrophytes. In: Mishra DR, Ogashawara I (eds) Bio-optical modeling and remote sensing of inland waters. Elsevier, Amsterdam, pp 263-308

Manzo C, Bresciani M, Giardino C, Braga F, Bassani C (2015) Sensitivity analysis of a bio-optical model for Italian lakes focused on Landsat-8, Sentinel-2 and Sentinel-3. Eur J Remote Sens 48(1):17-32

Markelin L, Simis SG, Hunter PD, Spyrakos E, Tyler AN, Clewley D, Groom S (2016) Atmospheric correction performance of hyperspectral airborne imagery over a small eutrophic lake under changing cloud cover. Remote Sens 9(1):2

Matthews MW (2017) Bio-optical modeling of phytoplankton chlorophyll-a. In: Mishra DR, Ogashawara I (eds) Bio-optical modeling and remote sensing of inland waters. Elsevier, Amsterdam, pp 157-182

Matthews MW, Odermatt D (2015) Improved algorithm for routine monitoring of cyanobacteria and eutrophication in inland and near-coastal waters. Remote Sens Environ 156:374-382

Mazel CH (1990) Spectral transformation of downwelling radiation by autofluorescent organisms in the sea. In: Ocean Optics X, vol 1302. International Society for Optics and Photonics, pp 320-328

Mazel CH (1995) Spectral measurements of fluorescence emission in Caribbean cnidarians. Mar Ecol Prog Ser 120:185-191

Mazel CH (1996) Coral fluorescence characteristics: excitation-emission spectra, fluorescence efficiencies, and contribution to apparent reflectance. SPIE Vol 2963 Ocean Opt XIII 1:240-245

Mazel CH, Fuchs E (2003) Contribution of fluorescence to the spectral signature and perceived color of corals. Limnol Oceanogr 48:390-401

Mazel CH, Lesser MP, Gorbunov MY, Barry TM, Farrel JH, Wyman KD et al (2003) Green-fluorescent proteins in Caribbean corals. Limnol Oceanogr 48:402-411

Mobley CD (1994) Light and water. Academic press, San Diego

Moore TS, Campbell JW, Dowell MD (2009) A class-based approach to characterizing and mapping the uncertainty of the MODIS ocean chlorophyll product. Remote Sens Environ 113:2424-2430

Morel A (2001) Bio-optical models. In: Thorpe SA (eds) Encyclopedia of ocean sciences. Academic press, San Diego, pp 317-326. https://doi.org/10.1006/rwos.2001.0407

Morel A, Maritorena S (2001) Bio-optical properties of oceanic waters: a reappraisal. J Geophys Res 106:7163-7180

Moses WJ, Sterckx S, Montes MJ, De Keukelaere L, Knaeps E (2017) Atmospheric correction for inland waters. In: Mishra DR, Ogashawara I (eds) Bio-optical modeling and remote sensing of inland waters. Elsevier, Amsterdam, pp 69-100

Mouw CB, Greb S, Aurin D, DiGiacomo PM, Lee Z, Twardowski M et al (2015) Aquatic color radiometry remote sensing of coastal and inland waters: challenges and recommendations for future satellite missions. Remote Sens Environ 160:15-30

Mouw C, Hardman-Montford N, Alvain S, Bracher A, Brewin R, Bricaud A, Ciotti A, Devred E, Fujiwara A, Hirata T, Hirawake T, Kostadinov T, Roy S, Uitz J (2017) A consumer's guide to satellite remote sensing of multiple phytoplankton groups in the global ocean. Front Mar Sci Res Topic CLEO. https ://doi.org/10.3389/fmars.2017.00041

Muller-Karger FE, Hestir E, Ade C, Turpie K, Roberts D, Siegel D, Miller R et al (2018) Satellite sensor requirements for monitoring essential biodiversity variables of coastal ecosystems. Ecol Appl. https:// doi.org/10.1002/eap.1682

Nair A, Sathyendranath S, Platt T, Morales J, Stuart V, Forget M-H, Devred E, Bouman H (2008) Remote sensing of phytoplankton functional types. Remote Sens Environ 112:3366-3375

Nechad B, Ruddick KG, Park Y (2010) Calibration and validation of a generic multisensor algorithm for mapping of Total Suspended Matter in turbid waters. Remote Sens Environ 114(4):854-866

Odermatt D, Gitelson A, Brando VE, Schaepman M (2012) Review of constituent retrieval in optically-deep and complex waters from satellite imagery. Remote Sens Environ 118:116-126

Olmanson LG, Bauer ME, Brezonik PL (2008) A 20-year Landsat water clarity census of Minnesota's 10,000 lakes. Remote Sens Environ 112(11):4086-4097

Olmanson LG, Brezonik PL, Bauer ME (2015) Remote sensing for regional lake water quality assessment: capabilities and limitations of current and upcoming satellite systems. In: Younos T, Parece TE (eds) Advances in watershed science and assessment. Springer, Cham, pp 111-140

Ozesmi SL, Bauer ME (2002) Satellite remote sensing of wetlands. Wetl Ecol Manag 10(5):381-402

Pahlevan N, Lee Z, Wei J, Schaaf CB, Schott JR, Berk A (2014) On-orbit radiometric characterization of OLI (Landsat-8) for applications in aquatic remote sensing. Remote Sens Environ 154:272-284

Paringit EC, Nadaoka K (2012) Simultaneous estimation of benthic fractional cover and shallow water bathymetry in coral reef areas from high-resolution satellite images. Int J Remote Sens 33:3026-3047 
Pierson DC, Strömbeck N (2001) Estimation of radiance reflectance and the concentrations of optically active substances in Lake Malaren, Sweden, based on direct and inverse solutions of a simple model. Sci Total Environ 268:171-188

Pinnel N (2007) A method for mapping submerged macrophytes in lakes using hyperspectral remote sensing. Limnologische Station, WZW, Department für Ökologie, Dissertation, p 164

Pozdnyakov D, Lyaskovsky A, Grassl H, Pettersson L (2002) Numerical modelling of transspectral processes in natural waters: implications for remote sensing. Int J Remote Sens 22:1581-1607

Preisendorfer RW (1961) Application of radiative transfer theory to light measurements in the sea. Union Geod Geophys Inst Monogr 10:11-30

Prezelin BB (1987) Photosynthetic physiology of dinoflagellates. In: Taylor FJF (ed) The biology of dinoflagellates. Blackwell Scientific Publications, Oxford, pp 174-223

Roelfsema CM, Phinn SR, Dennison WC (2002) Spatial distribution of benthic microalgae on coral reefs determined by remote sensing. Coral Reefs 21:264-274

Sadeghi A, Dinter T, Vountas M, Taylor B, Peeken I, Altenburg Soppa M, Bracher A (2012) Improvements to the PhytoDOAS method for identification of coccolithophores using hyper-spectral satellite data. Ocean Sci 8:1055-1070

Salem SI, Higa H, Kim H, Kazuhiro K, Kobayashi H, Oki K, Oki T (2017) Multi-algorithm indices and look-up table for chlorophyll-a retrieval in highly turbid water bodies using multispectral data. Remote Sens 9(6):556

Salih A, Larkum A, Cox G, Kühl M, Hoegh-Guldberg O (2000) Fluorescent pigments in corals are photoprotective. Nature 408:850-853

Santini F, Alberotanza L, Cavalli RM, Pignatti S (2010) A two-step optimization procedure for assessing water constituent concentrations by hyperspectral remote sensing techniques: an application to the highly turbid Venice lagoon waters. Remote Sens Environ 114(4):887-898

Sathyendranath S, Aiken J, Alvain S, Barlow R, Bouman H, Bracher A, Brewin R, Bricaud A, Brown CW, Ciotti AM, Clementson L, Craig SE, Devred E, Hardman-Mountford N, Hirata T, Hu C, Kostandinov TS, Lavender S, Loisel H, Moore TS, Morales J, Moulin C, Mouw CB, Nair A, Raitsos D, Roesler C, Shutler JD, Sosik H, Soto I, Stuart V, Subramaniam A, Uitz J (2014) Phytoplankton types from space. In: Sathyendranath S (ed) IOCCG report 15. Reports and Monography of the International Ocean Colour Coordination Group. http://www.ioccg.org/reports/IOCCG_Report_15_2014.pdf

Sathyendranath S, Brewin RJ, Jackson T, Mélin F, Platt T (2017) Ocean-colour products for climate-change studies: what are their ideal characteristics? Remote Sens Environ 203:125-138

Schaepman-Strub G, Schaepman ME, Painter TH, Dangel S, Martonchik JV (2006) Reflectance quantities in optical remote sensing-definitions and case studies. Remote Sens Environ 103:27-42

Schalles JF, Yacobi YZ (2000) Remote detection and seasonal patterns of phycocyanin, carotenoid and chlorophyll pigments in eutrophic waters. Arch Hydrobiol Spec Issues Adv Limnol 55:153-168

Schroeder T, Schaale M, Fischer J (2007) Retrieval of atmospheric and oceanic properties from MERIS measurements: a new Case-2 water processor for BEAM. Int J Rem Sens 28(24):5627-5632

Schwarz JN, Kowalczuk P, Kaczmarek S, Cota GF, Mitchell BG, Kahru M, Chavez FP, Cunningham A, McKee D, Gege P, Kishino M, Phinney DA, Raine R (2002) Two models for absorption by coloured dissolved organic matter (CDOM). Oceanologia 44:209-241

Shen F, Verhoef W, Zhou Y, Salama MS, Liu X (2010) Satellite estimates of wide-range suspended sediment concentrations in Changjiang (Yangtze) estuary using MERIS data. Estuaries Coasts 33(6):1420-1429

Simis SG, Olsson J (2013) Unattended processing of shipborne hyperspectral reflectance measurements. Remote Sens Environ 135:202-212

Sipelgas L, Arst H, Kallio K, Erm A, Oja P, Soomere T (2003) Optical properties of dissolved organic matter in Finnish and Estonian lakes. Nord Hydrol 34:361-386

Sokoletsky LG, Shen F (2014) Optical closure for remote-sensing reflectance based on accurate radiative transfer approximations: the case of the Changjiang (Yangtze) River Estuary and its adjacent coastal area, China. Int J Remote Sens 35:4193-4224

Sterckx S, Knaeps E, Bollen M, Trouw K, Houthuys R (2007) Retrieval of suspended sediment from advanced hyperspectral sesnor data in the scheldt estuary at different stages in the tidal cycle. Mar Geod 30:1-12

Sterckx S, Knaeps E, Ruddick K (2011) Detection and correction of adjacency effects in hyperspectral airborne data of coastal and inland waters: the use of the near infrared similarity spectrum. Int $\mathrm{J}$ Rem Sens 32(21):64796505

Strong AE (1974) Remote sensing of algal blooms by aircraft and satellite in Lake Erie and Utah Lake. Remote Sens Environ 3(2):99-107 
Stumpf RP, Wynne TT, Baker DB, Fahnenstiel GL (2012) Interannual variability of cyanobacterial blooms in Lake Erie. PLoS ONE 7(8):e42444

Toming K, Kutser T, Laas A, Sepp M, Paavel B, Nõges T (2016) First experiences in mapping lake water quality parameters with Sentinel-2 MSI imagery. Remote Sens 8(8):640

Tranvik LJ, Downing JA, Cotner JB, Loiselle SA, Striegl RG, Ballatore TJ, Dillon P et al (2009) Lakes and reservoirs as regulators of carbon cycling and climate. Limnol Oceanogr 54(6(2)):2298-2314

Tyler AN, Hunter PD, Spyrakos E, Groom S, Constantinescu AM, Kitchen J (2016) Developments in Earth observation for the assessment and monitoring of inland, transitional, coastal and shelf-sea waters. Sci Total Environ 572:1307-1321

Vanhellemont Q, Ruddick K (2014) Turbid wakes associated with offshore wind turbines observed with Landsat 8. Remote Sens Environ 145:105-115

Veron JEN (2000) Corals of the world. Australian Institute of Marine Science, Townsville

Verpoorter V, Loisel H, Dessailly D, Mauriaux X (2012) Optical classification of contrasted coastal waters. Remote Sens Environ 123:306-323

Verpoorter V, Kutser T, Seekel D, Tranvik L (2014) A global inventory of lakes based on high-resolution satellite imagery. Geol Rese Letters 41(18):6396-6402

Villa P, Bresciani M, Braga F, Bolpagni R (2014) Comparative assessment of broadband vegetation indices over aquatic vegetation. IEEE J STARS 7(7):3117-3127

Wang M, Shi W (2008) Satellite observed algae blooms in China's Lake Taihu. Eos Trans Am Geophys Union 89:201-202

Werdell PJ, Franz BA, Bailey SW, Feldman GC, Boss E, Brando VE, Dowell M, Hirata T, Lavender SJ, Lee Z, Loisel H (2013) Generalized ocean color inversion model for retrieving marine inherent optical properties. Appl Opt 52(10):2019-2037

Wolanin A, Soppa MA, Bracher A (2016) Investigation of spectral band requirements for improving retrievals of phytoplankton functional types. Remote Sens 8:871. https://doi.org/10.3390/rs8100871

Ylöstalo P, Seppälä J, Kaitala S, Maunula P, Simis S (2016) Loadings of dissolved organic matter and nutrients from the Neva River into the Gulf of Finland-Biogeochemical composition and spatial distribution within the salinity gradient. Mar Chem 186:58-71

Zepp RG, Schlotzhauer PF (1981) Comparison of photochemical behaviour of various humic substances in water: III. Spectroscopic properties of humic substances. Chemosphere 10:479-486 